\title{
Soft-Tissue Material Properties and Mechanogenetics during Cardiovascular Development
}

\author{
Hummaira Banu Siddiqui ${ }^{1}$ (D), Sedat Dogru ${ }^{1,2}$, Seyedeh Samaneh Lashkarinia ${ }^{1,3}$ and Kerem Pekkan ${ }^{1, *(1)}$ \\ 1 Department of Mechanical Engineering, Koc University, Istanbul 34450, Turkey; \\ hsiddiqui20@ku.edu.tr (H.B.S.); sdtdogru@gmail.com (S.D.); lashkarinia.samane@gmail.com (S.S.L.) \\ 2 Department of Biomedical Engineering, Boston University, Boston, MA 02215, USA \\ 3 Department of Bioengineering, Imperial College London, London SW7 2BX, UK \\ * Correspondence: kpekkan@ku.edu.tr; Tel.: +90-(533)-356-3595
}

Citation: Siddiqui, H.B.; Dogru, S.; Lashkarinia, S.S.; Pekkan, K. Soft-Tissue Material Properties and Mechanogenetics during Cardiovascular Development. J. Cardiovasc. Dev. Dis. 2022, 9, 64. https: / / doi.org/10.3390/ jcdd9020064

Academic Editor: Bradley B. Keller

Received: 3 November 2021

Accepted: 28 January 2022

Published: 21 February 2022

Publisher's Note: MDPI stays neutral with regard to jurisdictional claims in published maps and institutional affiliations.

Copyright: (C) 2022 by the authors. Licensee MDPI, Basel, Switzerland. This article is an open access article distributed under the terms and conditions of the Creative Commons Attribution (CC BY) license (https:/ / creativecommons.org/licenses/by/ $4.0 /)$.

\begin{abstract}
During embryonic development, changes in the cardiovascular microstructure and material properties are essential for an integrated biomechanical understanding. This knowledge also enables realistic predictive computational tools, specifically targeting the formation of congenital heart defects. Material characterization of cardiovascular embryonic tissue at consequent embryonic stages is critical to understand growth, remodeling, and hemodynamic functions. Two biomechanical loading modes, which are wall shear stress and blood pressure, are associated with distinct molecular pathways and govern vascular morphology through microstructural remodeling. Dynamic embryonic tissues have complex signaling networks integrated with mechanical factors such as stress, strain, and stiffness. While the multiscale interplay between the mechanical loading modes and microstructural changes has been studied in animal models, mechanical characterization of early embryonic cardiovascular tissue is challenging due to the miniature sample sizes and active/passive vascular components. Accordingly, this comparative review focuses on the embryonic material characterization of developing cardiovascular systems and attempts to classify it for different species and embryonic timepoints. Key cardiovascular components including the great vessels, ventricles, heart valves, and the umbilical cord arteries are covered. A state-of-the-art review of experimental techniques for embryonic material characterization is provided along with the two novel methods developed to measure the residual and von Mises stress distributions in avian embryonic vessels noninvasively, for the first time in the literature. As attempted in this review, the compilation of embryonic mechanical properties will also contribute to our understanding of the mature cardiovascular system and possibly lead to new microstructural and genetic interventions to correct abnormal development.
\end{abstract}

Keywords: cardiovascular microstructure; congenital heart defects; soft-tissue mechanics; strain energy; residual stresses; cardiovascular development; chick embryo; cardiovascular system; hemodynamics; arterial pressure; cardiac output; embryonic development; optical coherence tomography; heart-valve development; embryonic heart

\section{Introduction}

Embryonic cardiovascular development is an intriguing and vital process. This paper presents a comparative review of the material properties in the embryonic and fetal cardiovascular systems of different model organisms at consequent stages. An integrated and time-lapsed biomechanical and biochemical perspective of embryonic vascular remodeling and vascular growth is central to this review effort. In addition, the signaling pathways that ultimately regulate mechanical properties of major components of the dynamic vascular phenotype are also revisited. Recent advances in embryonic animal models of altered mechanical environment and increasing access to the mRNA interventions also motivated this review. It is expected that targeted combination of both interventions will start to emerge in the literature. Furthermore, the material properties such as stiffness [1], stress-strain 
measurements [1], strain rate [2], and elasticity [3] enunciate the structural and functional properties of the cardiovascular system and can help identify the emergence of congenital heart defects (CHDs). Shear stress-responsive elements stimulated by blood flow cause cellular activities; hence, the study of resulting mechanical properties would also provide insight into the functional evolution of the developing system [4]. Critical functions such as apoptosis, organogenesis, epithelial-mesenchymal transition during heart-valve development, and associated gene expressions are influenced or directly caused by the mechanical stresses [5]. Elasticity plays a crucial role in the efficient pumping mechanics of the ventricles [6]. Mechanical factors such as myocardial wall stress and strain [7,8], hemodynamics, and ventricular pressure [9-11] are also known to interfere with cardiac growth and development.

The stages of development of the embryo play a vital role in the targeted mechanical properties and their rate of change. System-level cardiovascular properties such as stiffness, compliance, and vascular resistance are significantly altered as the embryo develops [12]. While several empirical correlations have been drawn between the mechanical and morpho-structural properties of cardiovascular components [13], the properties are nonlinear and, hence, require a foundation of soft-tissue mechanics and custom experimental tools [3]. The survival and sustainability during embryogenesis may require a tight balance between the hemodynamic parameters and material characteristics [4]. Despite the overall changes during long-term development, some parameters such as stress-strain characteristics, stiffness, and stretch values tend to remain constant with growth, as demonstrated in key cardiovascular components [1]. Mechanical characterization is critical to detect cardiac anomalies with clinical significance at the early stages. An abnormality such as increased or decreased stresses, strains, or other mechanical factors can cause a fluctuation in the upstream transcription factors, which are indicative of the prevalence of cardiac defects [14-19]. Well-established transcription factors, such as KLF-2, ET1, and NOS3, are activated by wall shear stress [20-22]. Abnormalities in mechanical properties of the looping ventricle also have the potential to trigger CHDs $[8,23]$.

The biomechanics of cardiovascular development was initially investigated by a few pioneering research groups. Leading publications of these teams guided the present review systematics by providing the seed papers. Due to the authors' expertise and research interests, the recent experimental manuscripts published in specialized journals were screened from a biomedical and biomechanical engineering perspective. In this comparative review, for each species, we classified the cardiovascular system on the basis of its major components and compiled the embryonic stage-specific mechanical properties as they significantly change during development. The Carnegie stages (CS), a standardized 23-stage scale (up to 8 weeks of the human gestation period), are used as a scale to compare the embryonic development between different organisms [24].

The present review of embryonic mechanical characterization indicated gaps in literature where further experiments are needed. Therefore, two novel and noninvasive mechanical characterization techniques are introduced here for the first time in the literature. These techniques are applied to early avian embryonic stages and have the potential to address some of the experimental challenges discussed in this article.

The review starts with the basic methodology for measuring the material properties. The properties for avian embryos at key developmental stages are presented in detail due to the availability of ample data for this established cardiovascular animal model. Corresponding properties are compiled for porcine, human, and rat cardiovascular systems, in sequence. Despite the limited data and the complex/transitionary circulation system, Xenopus species are included for completeness [25]. The genetic impact of mechanical properties is reviewed, and the known interactions between the governing genes and morphology are presented. Thus, this review aims to establish insight into the relationship among mechanical properties, morphological structure, and genetic characteristics of the cardiovascular system as it develops into its more complex and fascinating mature configuration across species. 


\section{Materials and Methods}

\subsection{Traditional Methods}

Mechanical characterization includes basic mechanical testing and microscopic visualization, as summarized in Table 1. Experimental approaches include micropipette aspiration, optical stretching, optical tweezers, optical coherence tomography (OCT), micro cantilever-based techniques, pulsatile testing, and micro-indentation. These methods are used to observe mechanical factors such as stress-strain, elasticity, and strain energy function of soft tissues. The most popular and practical form of these techniques is tensile testing [13]. Tensile tests can be performed in a uniaxial or biaxial experimental setup to quantify the isotropic or anisotropic material properties of soft tissues, respectively [26-29]. However, they require the tissue to be extracted, and the quantification of small embryonic tissue properties locally via tensile testing is highly challenging, thus creating a niche for novel noninvasive methods.

Table 1. Summary of established mechanical techniques used to acquire the embryonic material properties and associated visualization methods.

\begin{tabular}{cccc}
\hline Mechanical Methods and Numerical Models & Ref. & Visualization Methods & Ref. \\
\hline Uniaxial/biaxial tensile testing & {$[30]$} & Optical coherence tomography & {$[31,32]$} \\
\hline Invasive/noninvasive residual stress experiments & {$[33]$} & Epifluorescence/fluoroscopy & Microscopy \\
\hline In vivo pressurization & {$[35]$} & Magnetic resonance imaging & Echocardiograph \\
\hline Optical stretching and optical tweezers & {$[37]$} & $[3], 36]$ & [18] \\
\hline Finite element modeling (FEM) & {$[29]$} & Confocal/two-photon microscopy & {$[19]$} \\
\hline Cantilever based technologies & {$[40]$} & Scanning electron microscopy \\
\hline Strain energy and Gasser-Ogden-Holzapfel models & {$[43]$} & Histology \\
\hline Cuts & {$[45]$} & Digital camera \\
\hline Micropipette aspiration with & {$[9,10]$} & Radiology \\
\hline Bervo-null pressure measurements & {$[32,46]$} & Micro computed tomography
\end{tabular}

To support the mechanical testing data, simultaneous visual observation of threedimensional changes of the tissue microstructure is important. Quantitative visualization techniques include fluorescence microscopy, two-photon/confocal imaging, magnetic resonance imaging and echocardiography [34]. Some researchers, as in [47], incorporate optical microstructural tracking with mechanical testing such as uniaxial, biaxial, and multiaxial testing, for better inference. The samples are subjected to loading until complete rupture and the stress-strain curve/stiffness is acquired [13]. Developmental changes in material properties are best observed using advanced microscopy [42]. These techniques are often optimized for a specific tissue or target cardiovascular component [14]. Multiple methods are also employed simultaneously for cross-validation, as in [3]. For high-quality research data, in utero and in ovo approaches are strongly preferred over the ex vivo or in vitro cultures of the developing cardiovascular components.

Due to the exponential nature of vascular stress-strain curves, the hyper-elastic exponential material model [48] is adopted to characterize the embryonic tissue [49,50]. For example, the Ogden material model [51] is commonly used, as employed by Von Dassow et al. [52] and Yao et al. [8] to model Xenopus laevis embryonic tissue and looping heart tissue in chick embryo, respectively. A simplified form of the Ogden material model is the neo-Hookean strain energy function, which was used in our recent work to characterize the growth of aortic arch tissue at early embryonic stages of the chick embryo [45]. 
Another basic material model for mechanical characterization of the soft tissue is Fung's material model [53,54]. Fung-type material is an anisotropic hyper-elastic constitutive model with the strain energy function described in [12]. Fung's equation represents a pseudo-elastic stress-strain relation (Equation (1)) and, thus, can be used to identify the corresponding nonlinear material parameters if the stresses and strains are experimentally evaluated.

$$
\rho_{o} W=\frac{c}{2} \exp Q
$$

where $\rho_{o}$ is the mass density, $W$ is the pseudo-strain energy per unit mass, $c$ is a constant with a unit of $\mathrm{kPa}$ (stress), and $Q$ is given by the following equation:

$$
Q=b_{1} E_{\theta}^{2}+b_{2} E_{z}^{2}+b_{3} E_{r}^{2}+2 b_{4} E_{\theta} E_{z}+2 b_{5} E_{z} E_{r}+2 b_{6} E_{r} E_{\theta}
$$

where $E_{0}, E_{z}$, and $E_{r}$ are Green's strain components in the circumferential, longitudinal, and radial directions, respectively, while $b_{1}, b_{2}, b_{3}, b_{4}, b_{5}$, and $b_{6}$ are the nonlinear material parameters and are constants for a given material. The values of $b_{n}$ correspond to the tissue structure, which determines the behavior of the material, although an explicit physical mechanical parameter cannot be assigned to the constants. Most importantly, these material models can be implemented in finite element modeling (FEM) frameworks to solve the detailed stress/strain distributions in subject-specific computational models of developing cardiovascular components [55-58].

\subsection{Novel Noninvasive Methods}

The first noninvasive technique introduced in this manuscript simultaneously measures lumen diameter and pressure waveforms over the cardiac cycle using OCT (Thorlabs, Newton, NJ, USA) and a servo-null pressure system (WPI, Sarasota, FL, USA) respectively. These measurements are sufficient to estimate both the unloaded and the loaded Fung's material parameters. Furthermore, the residual stresses can be acquired noninvasively as demonstrated in our earlier work applied to mature arteries [12]. For developing tissues, residual stresses are critical as their hyper-restoration is presumed to drive vascular growth [59]. In the present paper, we applied this technique to characterize embryonic pharyngeal arches and the vitelline arteries of early avian embryo using fertilized Gallus gallus domesticus eggs for Hamburger-Hamilton $(\mathrm{HH})$ stages [60] HH16 to HH24. This noninvasive data are presented for the first time in the literature. The experiments were conducted on five embryos to obtain the vitelline artery parameters and on eight embryos to obtain the IVth aortic arch vessel parameters, including their residual stress components and distribution. Since these experiments were conducted in ovo, results include external mechanical effects from albumin, including surface tension, as the embryo is oriented close to the air sac.

Alternatively, as the next noninvasive approach, an actuator was used to create a wave of frequency in the range $0-20 \mathrm{kHz}$, as in tissue elastography [61]. A signal with a desired amplitude was generated and directed at the chick embryo in ovo. A change in direction of the incident wave was observed in the OCT Doppler mode, depending on the local material properties the wave is reflected by. The change in the direction of frequency was recorded in the form of an image. Optimization of frequency and amplitude of the generated wave provided image data amiable for further analysis. The darker and lighter sections in the image are representative of the material characteristics of the tissue. A preliminary experimental setup of this technique is provided in Figure 1. 


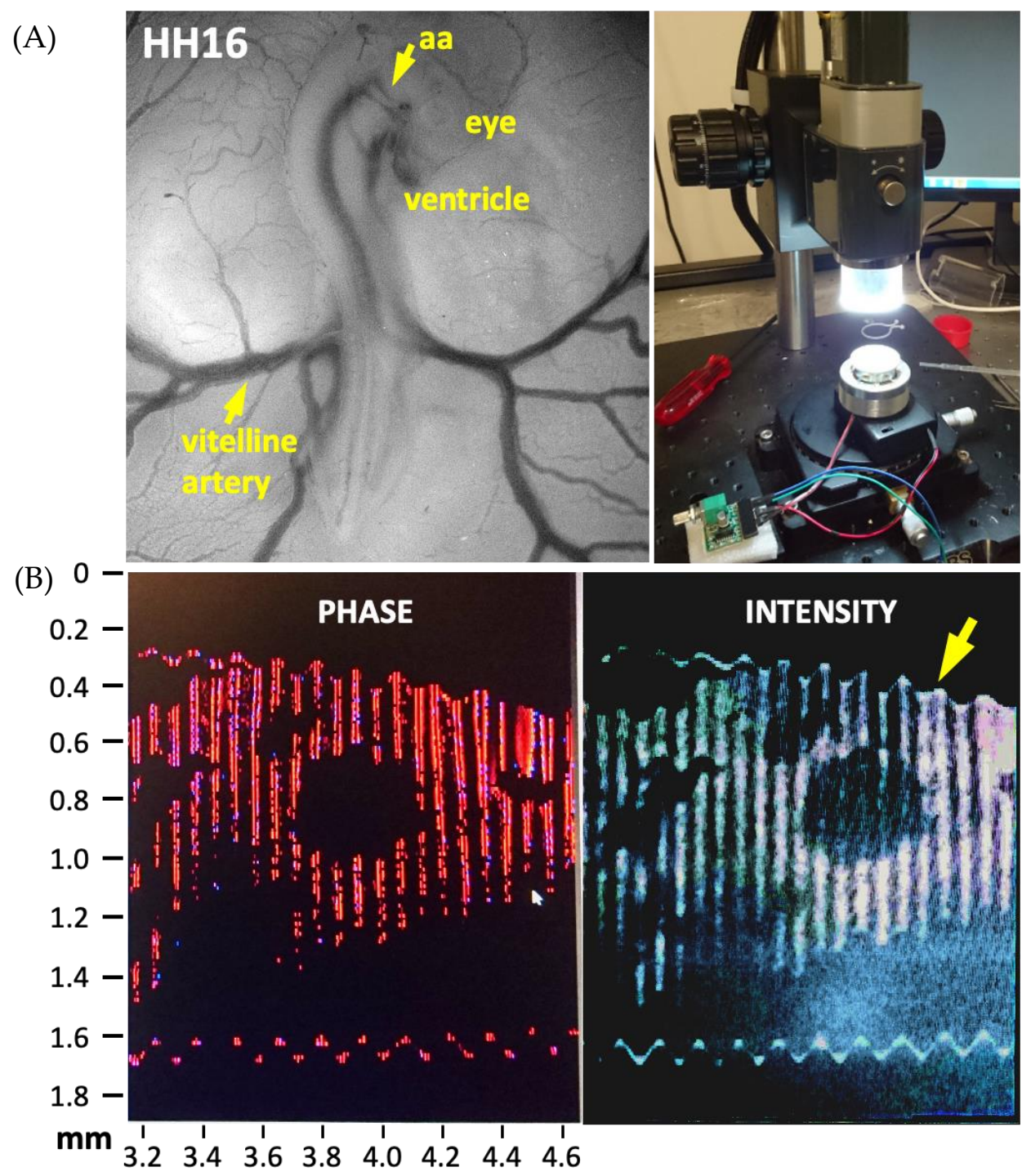

Figure 1. The experimental setup used to evaluate material properties in chick embryos at HH16 (vitelline artery) to HH24 (aortic arch, aa) is shown on the right. (A). Stage HH16 chick embryo imaged under a stereomicroscope is also provided. (B). Preliminary optical coherence tomography images of chick ventricle during acoustic forcing $(0-20 \mathrm{kHz})$ performed for noninvasive elastography. A cross-section of the ventricle is displayed. The arrow points to the instantaneous deformation of the soft tissue.

\section{Results}

\subsection{Avian Embryonic Development}

Avian embryos, such as quail and chick, are the models of choice as they closely relate to the biventricular human cardiovascular system [62] and enable a large sample size. In the literature, material properties have been studied for a broad range of embryonic $\mathrm{HH}$ stages and cardiovascular components, as summarized below.

\subsubsection{Ventricles}

Anatomical dimensions are first reviewed in order to provide an interpretation for the reported stress / strain levels and other mechanical properties. The left ventricle (LV) compact layer thickness, which excludes the trabeculations, is larger than that of the right ventricle (RV) from HH24 to HH34 [63]. Compact layer thickness is $45 \mu \mathrm{m}$ and $35 \mu \mathrm{m}$ at $\mathrm{HH} 34$ and HH24, respectively, for LV and $35 \mu \mathrm{m}$ and $15 \mu \mathrm{m}$ at $\mathrm{HH} 34$ and HH24, respectively, for RV. The total volume of the myocardium for a healthy embryo was observed to be 
$\sim 0.7 \mathrm{~mm}^{3}$ and $\sim 0.35 \mathrm{~mm}^{3}$ for the LV and RV, respectively, for combined compact and trabecular regions [63]. The LV wall thickness, including the trabeculae, is $\sim 300 \mu \mathrm{m}$ at $\mathrm{HH} 27$, and it progressively increases to $440 \mu \mathrm{m}$ at HH31 [63]. At HH29, the length of the $\mathrm{RV}$ and LV is approximately $1.25 \mathrm{~mm}$ and $1.75 \mathrm{~mm}$, which increases to $3.5 \mathrm{~mm}$ and $5.5 \mathrm{~mm}$ at $\mathrm{HH} 40$, respectively [63]. Embryonic ventricular dimensions can also be estimated from published developmental atlases [64].

Earlier studies acquired the progressive changes in ventricular tissue strain values. For Leghorn chick embryo at HH16, micropipette aspiration was employed to measure the circumferential and peak axial Lagrange strain of the embryonic ventricle, indicating that the strains are different for systole and diastole, with the peak strain being $-0.16 \pm 0.08$. There is a shortening of about $20 \%$ during systole [65]. Strain is higher near the boundaries of the primitive RV and reduces close to the mid-ventricle. Higher strain values imply potential for remodeling and enhanced biomolecular activity. The stiff myocardium supports the end-systolic pressure load indicated by the transmural stress distribution, accounting for the effects of residual strain. Residual stress levels significantly affect the stress distribution of the loaded state. For example, residual stress increases the stress concentration of the myocardial layer at HH17 [66]. For time-lapsed data, the noninvasive residual stress estimation approach introduced in Section 2.2 can also be applied to the ventricles.

At HH18, using uniaxial loading and FEM, the changes in the strain values between HH16 and HH18 were reported by Miller et al. [67]. The longitudinal Lagrangian strain of the ventricles was calculated from three microspheres at the top center of the outer curvature and reached a maximum value of 0.19 at HH18. The cross-sectional area at HH16 was observed to be $0.049 \mathrm{~mm}^{2}$ and that at HH18 was observed to be $0.059 \mathrm{~mm}^{2}$ [67], indicating an increase in the thickness of the ventricles. An increase in strain indicates an improvement in the ventricles' capacity to withstand increased blood pressure during development. As the stages progress, the strain levels increase, as presented in Figure 2.

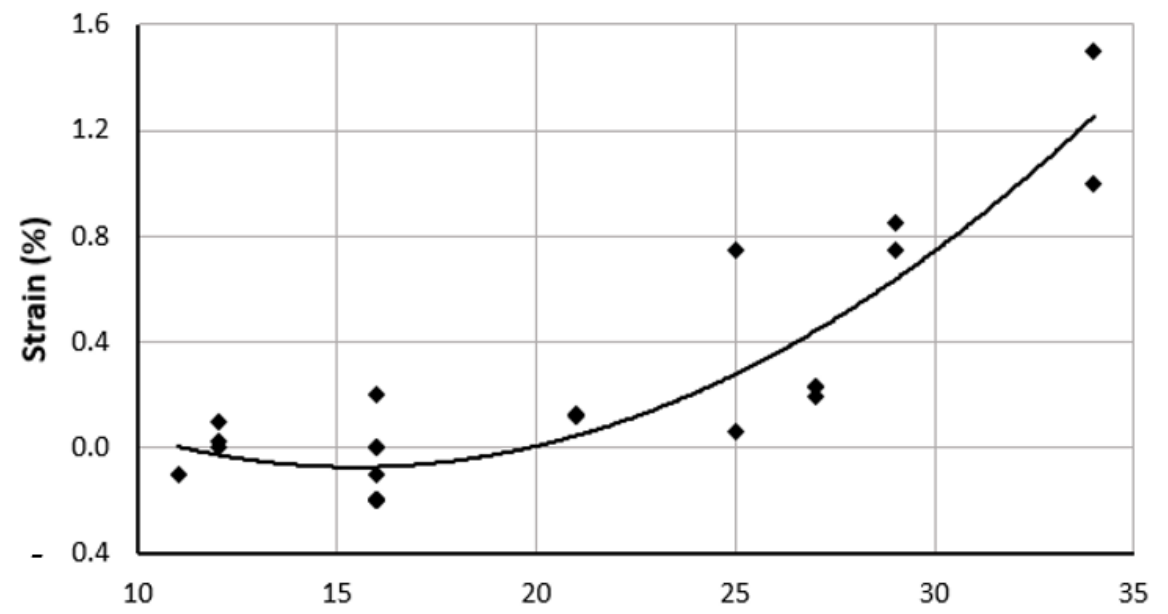

Figure 2. Overall strain trend of embryonic chick ventricles (LV and RV) presented as a percentage, as compiled from multiple literature sources, from HH11 to HH34. Corresponding references are cited in the text and in Table 2. HH: Hamburger-Hamilton stages.

Cyclic uniaxial loading of the LV shown by Miller et al. [67] at HH16 showed that the longitudinal strain ranges from 0.0 to 0.25 , circumferential strain ranges from -1.5 to -0.01 , and shear strain remains approximately zero. Thus, circumferential strains are negative, and longitudinal strains are positive. The thickness of the LV wall increases from $300 \mu \mathrm{m}$ to $400 \mu \mathrm{m}$, from HH27 to HH31, respectively.

The conotruncal banding model (CTB) results in an acute increase in ventricular pressure leading to an abnormal development. Miller et al. [30] showed that when the LV of Leghorn chicks with CTB is subjected to biaxial loading, the stress/strain values 
remain unchanged from $\mathrm{HH} 27$ to $\mathrm{HH} 31$. This contrasts with the healthy LV development, for which these values decrease as the embryo develops, supporting the hypothesis that mechanical uniaxial loading primarily regulates the trabecular aspect [30]. Another study on the CTB model reported ventricular dilation, thickening of the compact myocardium and trabeculae, and spiraling of trabecular course in the LV [65]. Since the ventricle is an anisotropic material, strains evaluated along different axes result in different values. For this review, we report the circumferential strain while briefly exploring longitudinal strains. The circumferential strain is evaluated for a circular vessel from the inner radius to the outer radius. Values compiled from literature are summarized in Table 2, along with their equivalent Carnegie stages, to allow for a timeline comparison across different species.

Tobita et al. observed the mechanical behavior of ventricle strains at LV and RV measured for stages HH21 to HH31 [10], along the circumferential and longitudinal directions. Tobita et al. observed that the strain consistently increased with embryonic stage. Epicardial wall strain at end of diastole at $\mathrm{HH} 11$ and $\mathrm{HH} 27$ for the circumferential and longitudinal orientations at LV and RV was also reported [68]. As the embryo develops, strain increases linearly along all axes [69]. Table 2 summarizes the strain levels reported in the literature from HH11 to HH35. It is observed that LV consistently has a lower longitudinal strain than RV and a higher circumferential strain than RV [10].

Table 2. Material properties of embryonic ventricles are summarized for the avian embryo. Regional properties of ventricles, epicardium, valve leaflets/cushions, atrioventricular region, myocardial wall, dorsal aorta, and atrium are compiled as available in the literature. Properties were evaluated at different embryonic stages primarily using the methods in Table 1. Reference sources (Ref.) are provided in the first column. LV: left ventricle, MPA: micropipette aspiration, RV: right ventricle, CTB: conotruncal banding, LAL: left-atrial ligation, FEM: finite element modeling, AV: atrioventricular, CS: Carnegie stage.

\begin{tabular}{|c|c|c|c|c|c|c|c|}
\hline \multirow{2}{*}{ Ref. } & \multirow{2}{*}{$\begin{array}{c}\text { Vascular } \\
\text { Component }\end{array}$} & \multirow{2}{*}{ Parameter } & \multirow{2}{*}{ Type } & \multicolumn{2}{|c|}{ Stage } & \multirow{2}{*}{ Value } & \multirow{2}{*}{ Method } \\
\hline & & & & HH & $\mathrm{CS}$ & & \\
\hline \multicolumn{8}{|c|}{ Ventricle Looping } \\
\hline \multirow{6}{*}[43]{} & \multirow{6}{*}{ ventricle looping } & \multirow{2}{*}{ Pressure $(\mathrm{kPa})$} & systolic & \multirow{6}{*}{16} & \multirow{6}{*}{12.6} & 0.133 & \multirow{6}{*}{$\begin{array}{l}\text { Computational model } \\
\text { and cuts }\end{array}$} \\
\hline & & & diastolic & & & 0.033 & \\
\hline & & Stress $(\mathrm{kPa})$ & Cauchy & & & 2 & \\
\hline & & \multirow{3}{*}{ strain } & $\max$ & & & 0 & \\
\hline & & & $\min$ & & & -0.2 & \\
\hline & & & bending & & & -0.2 & \\
\hline & & & Epicardium & & & & \\
\hline \multirow{6}{*}{ [9] } & \multirow{6}{*}{ epicardium } & \multirow{3}{*}{ strain } & $\max$ & \multirow{6}{*}{16} & \multirow{6}{*}{12.6} & 0 & \multirow{6}{*}{ epicardial beads } \\
\hline & & & $\min$ & & & -0.2 & \\
\hline & & & bending & & & -0.2 & \\
\hline & & stress $(\mathrm{kPa})$ & $\max$ & & & 4 & \\
\hline & & \multirow{2}{*}{ strain } & $\max$ & & & -0.1 & \\
\hline & & & $\min$ & & & -0.2 & \\
\hline \multirow{4}{*}[68]{} & \multirow{4}{*}{ epicardial } & \multirow{4}{*}{ strain } & $\max \operatorname{circ}$ & 11 & 11 & -0.1 & \multirow{4}{*}{ triangular array } \\
\hline & & & max inner & 12 & 11 & 0.1 & \\
\hline & & & systole bending & 12 & 11 & 0.02 & \\
\hline & & & diastole bending & 12 & 11 & 0 & \\
\hline
\end{tabular}


Table 2. Cont.

\begin{tabular}{|c|c|c|c|c|c|c|c|}
\hline \multirow{2}{*}{ Ref. } & \multirow{2}{*}{$\begin{array}{c}\text { Vascular } \\
\text { Component }\end{array}$} & \multirow{2}{*}{ Parameter } & \multirow{2}{*}{ Type } & \multicolumn{2}{|c|}{ Stage } & \multirow{2}{*}{ Value } & \multirow{2}{*}{ Method } \\
\hline & & & & HH & CS & & \\
\hline \multicolumn{8}{|c|}{ Ventricle } \\
\hline [67] & ventricle & strain & $\max$ & 16 & 12.6 & 0.2 & MPA \\
\hline \multirow{3}{*}[30]{} & \multirow{3}{*}{ LV } & \multirow{3}{*}{$\begin{array}{l}\text { thickness } \\
\text { (microns) }\end{array}$} & & 27 & 17.5 & 300 & \multirow{3}{*}{$\begin{array}{l}\text { uniaxial and biaxial } \\
\text { testing }\end{array}$} \\
\hline & & & & 29 & 19 & 400 & \\
\hline & & & & 31 & 20 & 425 & \\
\hline \multirow{6}{*}{ [63] } & \multirow{4}{*}{ LV } & \multirow{6}{*}{$\begin{array}{l}\text { thickness } \\
\text { (microns) }\end{array}$} & \multirow{6}{*}{ compact layer } & 24 & 16 & 30 & \multirow{6}{*}{$\begin{array}{c}\text { Micro-indentation and } \\
\text { FEM }\end{array}$} \\
\hline & & & & 29 & 19 & 40 & \\
\hline & & & & 34 & 21 & 45 & \\
\hline & & & & 24 & 16 & 40 & \\
\hline & \multirow[t]{2}{*}{ RV } & & & 29 & 19 & 60 & \\
\hline & & & & 34 & 21 & 70 & \\
\hline \multirow{6}{*}[10]{} & \multirow{3}{*}{$\mathrm{LV}$} & & \multirow{2}{*}{ circumferential } & 21 & 15 & 0.12 & \multirow{6}{*}{ Beads } \\
\hline & & & & 27 & 17.5 & 0.23 & \\
\hline & & tmain & end diastole & 21 & 15 & 0.12 & \\
\hline & RV & strain & \multirow{3}{*}{ circumferential } & 21 & 15 & 0.13 & \\
\hline & RV & & & 27 & 17.5 & 0.23 & \\
\hline & $\mathrm{LV}$ & & & 27 & 17.5 & 0.19 & \\
\hline \multirow{2}{*}[7]{} & \multirow{3}{*}{ ventricle } & \multirow{3}{*}{ pressure $(\mathrm{kPa})$} & systole max & 21 & 15 & 0.2 & \multirow{3}{*}{$\begin{array}{l}\text { Cuts, theoretical } \\
\text { model, and } \\
\text { Micro-pressure system }\end{array}$} \\
\hline & & & diastole max & 21 & 15 & 0.067 & \\
\hline [70] & & & $\max$ & 24 & 16 & 0.06 & \\
\hline$[65]$ & myocardial & circumferential & RV & 27 & 17.5 & 4.3 & \\
\hline [00] & myocarcial & stiffness constant & $\mathrm{LV}$ & 27 & 17.5 & 7.8 & Beads \\
\hline & & pressure & max diastole & & & 0.631 & FFM Servo-nressure \\
\hline [19] & IV & $(\mathrm{kPa})$ & max systole & 29 & 19 & 0.062 & FEVI servo-pressure \\
\hline & LV & stress $(\mathrm{kPa})$ & von mises & 29 & 19 & 1 & \\
\hline & & strain & von mises & & & 0.5 & $C_{11 t c}$ \\
\hline [8] & ventricle & stress $(\mathrm{kPa})$ & residual & 12 & 11 & 27.2 & Cuts \\
\hline$[71]$ & cardiac jelly & stiffness $(\mathrm{N} / \mathrm{m})$ & $\max$ & 12 & 11 & 0.00225 & \\
\hline & & & Valve Leafle & & & & \\
\hline & septal & & & 25 & 16.5 & 0.3 & \\
\hline & mural & & & 25 & 16.5 & 0.75 & \\
\hline [49] & septal & strain energy & eneroy density & 29 & 19 & 0.85 & FFM \\
\hline [49] & mural & density $(\mathrm{Pa})$ & energy density & 29 & 19 & 0.75 & FEM \\
\hline & septal & & & 34 & 21 & 1.5 & \\
\hline & mural & & & 34 & 21 & 1 & \\
\hline
\end{tabular}


Table 2. Cont.

\begin{tabular}{|c|c|c|c|c|c|c|c|}
\hline \multirow{2}{*}{ Ref. } & \multirow{2}{*}{$\begin{array}{l}\text { Vascular } \\
\text { Component }\end{array}$} & \multirow{2}{*}{ Parameter } & \multirow{2}{*}{ Type } & \multicolumn{2}{|c|}{ Stage } & \multirow{2}{*}{ Value } & \multirow{2}{*}{ Method } \\
\hline & & & & $\mathbf{H H}$ & CS & & \\
\hline \multicolumn{8}{|c|}{ Atrio Ventricular region } \\
\hline \multirow{3}{*}{ [72] } & \multirow{3}{*}{ AV region } & \multirow{3}{*}{$\begin{array}{l}\text { modulus } \\
(\mathrm{kPa})\end{array}$} & \multirow{3}{*}{$\begin{array}{l}\text { effective mod } \\
\text { cushion }\end{array}$} & 17 & 13 & 0.0001 & \multirow{3}{*}{$\begin{array}{l}\text { Micro pipette } \\
\text { aspiration }\end{array}$} \\
\hline & & & & 21 & 15 & 0.001 & \\
\hline & & & & 25 & 16.5 & 0.004 & \\
\hline \multirow{3}{*}[41]{} & \multirow{3}{*}{ AV canal } & \multirow{3}{*}{ stress $(\mathrm{kPa})$} & Shear min & 24 & 16 & 0.002 & \multirow{3}{*}{ Immunofluorescence } \\
\hline & & & Shear min & 28 & 18 & 0.002 & \\
\hline & & & Shear min & 30 & 19 & 0.002 & \\
\hline \multicolumn{8}{|c|}{ Myocardial Wall } \\
\hline \multirow{3}{*}[2]{} & \multirow{3}{*}{ myocardial wall } & strain $(\%)$ & $\max$ & \multirow{3}{*}{18} & \multirow{3}{*}{13.5} & 70 & \multirow{3}{*}{ Doppler OCT } \\
\hline & & strain rate $(1 / \mathrm{s})$ & rate & & & 5 & \\
\hline & & thickness (mm) & & & & 0.85 & \\
\hline \multicolumn{8}{|c|}{ Aorta Dorsal } \\
\hline$[4]$ & $\begin{array}{l}\text { aortic } \\
\text { (dorsal) }\end{array}$ & pressure $(\mathrm{kPa})$ & range & 27 & 17.5 & $0-0.180$ & $\begin{array}{l}\text { LAL and Velocimeter } \\
\text { pressure measurement }\end{array}$ \\
\hline \multicolumn{8}{|c|}{ Atrium } \\
\hline \multirow{3}{*}[41]{} & \multirow{3}{*}{ atrium } & \multirow{3}{*}{ stress $(\mathrm{kPa})$} & \multirow{3}{*}{ shear min } & 24 & 16 & 0.0128 & \multirow{3}{*}{$\begin{array}{l}\text { Stress sensors and } \\
\text { Immunofluorescence }\end{array}$} \\
\hline & & & & 28 & 18 & 0.0118 & \\
\hline & & & & 30 & & 0.0128 & \\
\hline
\end{tabular}

Myocardial stiffness as an index of resistance to deformation, at stages HH21 and HH27, was measured by Tobita et al. [65] for LV and RV. The stiffness constant is a dimensionless quantity derived from the following equation: $\sigma=a \times \exp (b E)$ and reported for the normal embryo at $\mathrm{HH} 27$. The stiffness constant of RV is 4.5 and 5.4 circumferentially and longitudinally, respectively. The corresponding values of stiffness constant for LV are 7.8 and 9.6, in which the longitudinal stiffness is higher than circumferential stiffness [65]. LV is stiffer that RV due to reduced volume load compared to LV.

At $\mathrm{HH} 24$, the end-diastolic stiffness reported by Stekelenburg et al. [20] was $0.6 \mathrm{mmHg} / \mu \mathrm{L}$ for a healthy embryo. A decrease in passive filling is observed for stiffer ventricular walls. The relative weight of the embryo remains constant between HH12 and HH29. The effective elastance obtained from pressure-volume loops indicates the contractility of the heart. Contractility, defined as the ability of a muscle tissue to shrink, is estimated to be $7.53 \mathrm{mmHg} / \mu \mathrm{L}$ [20]. $\mathrm{HH} 21$ has a higher diastolic stiffness than $\mathrm{HH} 24$, indicating a decrease in stiffness and increase in elasticity as the embryonic timeline progresses. As expected, stresses differ during the contraction and relaxation phases of the heart; at the end-diastole, for $\mathrm{HH} 21$, it was measured to be between $15-20 \mathrm{mmHg}$, whereas, at end-systole, it is between $100-150 \mathrm{mmHg}$ [69].

Strains are measured for the ventricles at the outer curvature, the center, and the inner curvature for $\mathrm{HH} 11$ and $\mathrm{HH} 12$. While the microstructural properties are similar at the outer curvature and for the inner curvature, the circumferential direction has higher contractile stress levels. Strains at stages HH11 and HH12 are not significantly different but are higher in the central region for HH11 along both cardiac axes [68]. Strain values compiled from the literature show an increasing trend, as displayed in Figure 2.

Biaxial wall stress-strain relations also differ for the LV and RV as expected. Stress values peak at $\mathrm{HH} 27$ at any given strain level for both ventricles; however, for a CTB model, peak strain was observed at $\mathrm{HH} 21$ [65]. 


\subsubsection{Heart Valves}

For atrioventricular valve leaflets at $\mathrm{HH} 25$ to $\mathrm{HH} 34$, the corresponding strain energy density functions were provided in [49], by utilizing two different experimental approaches. Deformable cantilevers were used for stages $\mathrm{HH} 25$ to HH34, whereas micropipette aspiration was used for stage HH36. It was observed that the strain energy density of the leaflet at HH36 is four times that at HH34. The strain energy density was also observed to increase by a factor of 2.5 from $\mathrm{HH} 25$ to $\mathrm{HH} 29$. Along the embryonic leaflet, the superior cushion region had a strain energy density of $0.44 \mathrm{~Pa}$, while the inferior had a strain energy density of $0.34 \mathrm{~Pa}$. Mural strain energies were observed to change from 0.6 Pa to 0.9 Pa between $\mathrm{HH} 29$ and HH34, respectively. Other available values from the literature are provided in Table 2.

\subsubsection{Aortic Arch and Vitelline Artery Properties Geometry}

Three paired aortic arch vessels appear in the development of early chick embryo. Wang et al. [73] studied the diameter of four of the six aortic arches and characterized the wall shear stress for these vessels. They observed that the midpoint diameters of the right arches are greater than the left and are in the range of 0.101 to $0.129 \mathrm{~mm}$ for HH18 and 0.113 to $0.138 \mathrm{~mm}$ for $\mathrm{HH} 24$, respectively [73]. Another study by Celik et al. evaluated the aortic arch diameters; at HH24, the maximum diameter was $0.3 \mathrm{~mm}$ [74]. Lindsey et al. studied the diameter upon occlusion at HH18 and HH24 and found it to be $\sim 0.2 \mathrm{~mm}$ [75].

\section{Vascular Function, Pressure-Diameter Loops}

In this section, employing the noninvasive approach described in Section 2.2 using pressure-diameter measurements acquired in vivo, a detailed mechanical analysis of vitelline arteries and the IVth aortic arch is presented. For both vessels, measurements indicate that the diameter increases nonuniformly with an increase in pressure (Figure 3). Another important finding is the existence of hysteresis during early stages as loading and unloading cycles are significantly different. Further studies are needed to quantify the level of hysteresis during later embryonic stages and how it is probably reduced in relation to the microstructure.

Pressure-diameter loops and the vessel thickness change during the cardiac cycle were used to obtain the Fung's strain energy constants for both arteries using the method introduced by Donmazov et al. [12]. The values for the constants from Equation (2) were calculated and are presented in Table 3.

Vitelline artery: As presented in Table 3, the constant $c$ is related to residual stress and increases with the stage of the embryo, as expected from pressure measurements and opening angle data. Constant $b_{1}$ decreases as the embryo develops, and $b_{3}$ nearly remains constant, while all other parameters $\left(b_{2}, b_{4}, b_{5}\right.$, and $\left.b_{6}\right)$ increase during the growth of the vitelline artery. Due to in vivo measurements, a slight irregularity in loading curves is recorded. These parameters were evaluated under loading and unloading conditions. For example, it is observed that the constant $c$ displayed a similar trend for both conditions, although the increment was steeper for loading. All other parameters had a similar trend for both loading and unloading conditions from HH16 to HH19.

Aortic arch vessels: Aortic arch vessels behaved differently as compared to vitelline artery during growth. The calculated Fung's strain energy function parameters were similar for each stage, confirming the calculations noted in Table 3 . The constant $c$ increases with stage, $b_{3}$ and $b_{4}$ are nearly constant, and $b_{1}, b_{2}, b_{5}$, and $b_{6}$ decrease as the aortic arch grows. When these parameters were observed during loading and unloading conditions, parameter $c$ followed the same trend for both with a steeper increase during loading. All other parameters had a similar behavior during both loading and unloading. 
(A)

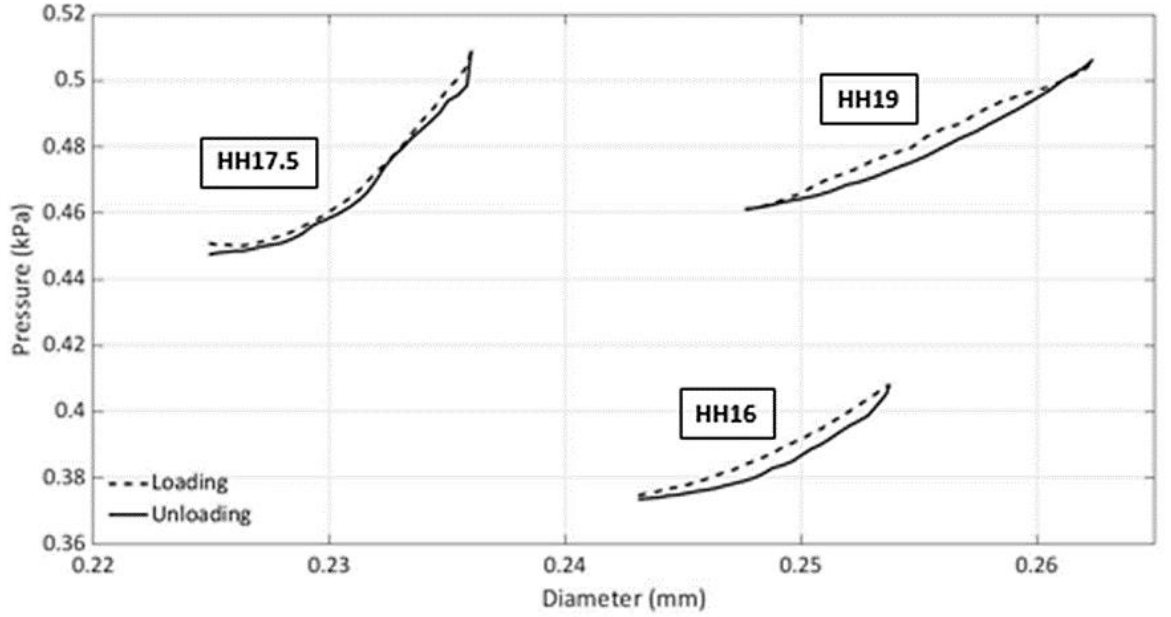

(B)

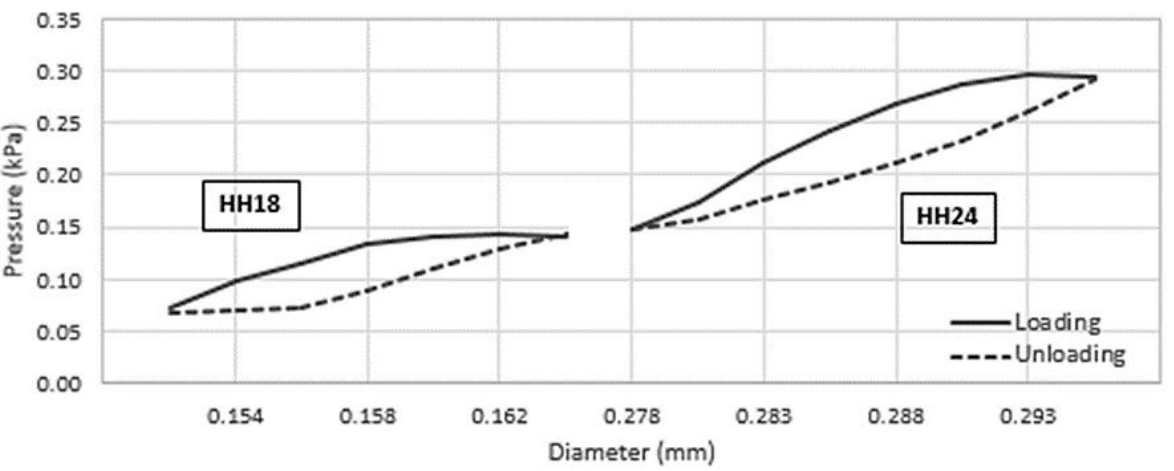

Figure 3. Representative pressure vs. lumen diameter loops of chick embryonic arteries acquired in vivo. (A). The vitelline arteries under loading and unloading conditions over the cardiac cycle The data were collected for eight embryos (one representative sample shown) at three consequent stages of HH16, HH17.5, and HH19. (B). Right IVth aortic arch loading and unloading data over the cardiac cycle. The data were collected for five embryos (one sample shown) at two consequent stages of HH18 and HH24. Other sample data are available in the Supplementary Materials, and statistics are provided in Table 3. Data were acquired simultaneously using OCT and the servo-null pressure system described in Section 2.2.

Table 3. Estimated Fung's strain energy function parameters (Equation (1)) for loading and unloading at HH16, HH17.5, and HH19 for the vitelline artery vessels and for the IVth aortic arch at HH18 and $\mathrm{HH} 24$ are tabulated. Sample numbers $(n)$ are indicated for each artery type.

\begin{tabular}{|c|c|c|c|c|c|c|c|c|c|c|c|c|c|}
\hline \multicolumn{8}{|c|}{ Vitelline Artery $(n=5)$} & \multicolumn{6}{|c|}{ Aortic Arch $(n=8)$} \\
\hline \multicolumn{4}{|c|}{ Loading } & \multicolumn{4}{|c|}{ Unloading } & \multicolumn{3}{|c|}{ Loading } & \multicolumn{3}{|c|}{ Unloading } \\
\hline HH & 16 & 17.5 & 19 & & 16 & 17.5 & 19 & & 18 & 24 & & 18 & 24 \\
\hline$c$ & $0.46 \pm 0.03$ & $0.51 \pm 0.04$ & $0.58 \pm 0.04$ & $c$ & $0.43 \pm 0.03$ & $0.47 \pm 0.04$ & $0.57 \pm 0.04$ & $c$ & $0.51 \pm 0.03$ & $0.61 \pm 0.07$ & $c$ & $0.48 \pm 0.02$ & $0.57 \pm 0.06$ \\
\hline$b 1$ & $4.68 \pm 0.14$ & $4.45 \pm 0.14$ & $4.23 \pm 0.13$ & $b 1$ & $4.49 \pm 0.14$ & $4.14 \pm 0.13$ & $4.1 \pm 0.12$ & $b 1$ & $6.51 \pm 0.19$ & $5.00 \pm 0.25$ & $b 1$ & $6.09 \pm 0.18$ & $4.68 \pm 0.24$ \\
\hline$b 2$ & $2.81 \pm 0.14$ & $3.12 \pm 0.15$ & $3.28 \pm 0.16$ & $b 2$ & $2.69 \pm 0.13$ & $2.91 \pm 0.14$ & $3.18 \pm 0.15$ & $b 2$ & $2.53 \pm 0.07$ & $2.13 \pm 0.07$ & $b 2$ & $2.37 \pm 0.07$ & $1.99 \pm 0.07$ \\
\hline$b 3$ & $0.65 \pm 0.02$ & $0.67 \pm 0.02$ & $0.65 \pm 0.02$ & $b 3$ & $0.63 \pm 0.02$ & $0.62 \pm 0.02$ & $0.63 \pm 0.02$ & $b 3$ & $0.63 \pm 0.05$ & $0.59 \pm 0.06$ & $b 3$ & $0.59 \pm 0.05$ & $0.55 \pm 0.05$ \\
\hline$b 4$ & $0.37 \pm 0.03$ & $0.45 \pm 0.04$ & $0.51 \pm 0.04$ & $b 4$ & $0.36 \pm 0.03$ & $0.42 \pm 0.03$ & $0.50 \pm 0.04$ & $b 4$ & $0.32 \pm 0.02$ & $0.27 \pm 0.03$ & $b 4$ & $0.30 \pm 0.02$ & $0.26 \pm 0.03$ \\
\hline$b 5$ & $6.04 \pm 0.14$ & $7.07 \pm 0.17$ & $7.86 \pm 0.19$ & $b 5$ & $5.80 \pm 0.14$ & $6.58 \pm 0.16$ & $7.62 \pm 0.18$ & $b 5$ & $6.40 \pm 0.12$ & $5.11 \pm 0.12$ & $b 5$ & $5.99 \pm 0.11$ & $4.77 \pm 0.11$ \\
\hline$b 6$ & $1.47 \pm 0.03$ & $1.76 \pm 0.04$ & $1.86 \pm 0.04$ & $b 6$ & $1.41 \pm 0.03$ & $1.64 \pm 0.04$ & $1.81 \pm 0.04$ & $b 6$ & $0.98 \pm 0.03$ & $0.90 \pm 0.03$ & $b 6$ & $0.91 \pm 0.03$ & $0.84 \pm 0.03$ \\
\hline
\end{tabular}

Effective Opening Angle and Residual Stress

Effective opening angle is derived from the loaded and unloaded ventricular morphology, as employed in the experiments conducted by Taber et al. on embryonic chick ventricles at $\mathrm{HH}$ stages 16, 18, 21, and 24 [69]. The effective opening angle increases as the stiffness of the vessel increases ( $31^{\circ}$ at HH16), which is the residual stress component in one direction. Residual stress components along the orthogonal directions require additional 
incisions for the invasive approach. For the micron-size embryonic arteries, these experiments are very challenging to perform. As an alternative, herein, we present the results obtained from our non-invasive measurements based on Donmazov et al. [12]. Supplementary Figures S1 and S2 show the measured embryonic residual stress trends through the vessel wall along the radial $(\mathrm{r})$, longitudinal $(\mathrm{z})$, and circumferential $(\theta)$ directions. Residual stresses were computed for the vitelline artery and for the IVth aortic arch. It was found that, for the increased loading condition, residual stresses are greater than for unloading for both vitelline artery and aortic arch. In addition, an increase was observed in the values of residual stresses as the vessels grow.

Vitelline artery: As plotted in Figure 4, it can be concluded that the vitelline artery at HH19 is stiffer than at HH16. Moreover, the sharp increase in its effective angle from stage HH17.5 to HH19 confirms this finding. Axial residual stress increases from $0.3 \mathrm{kPa}$ to $0.4 \mathrm{kPa}$ between the stages HH16 and HH19. The increase in residual stress in the circumferential direction and the radial direction is similar $(\sim 0.5 \mathrm{kPa})$.

(A)

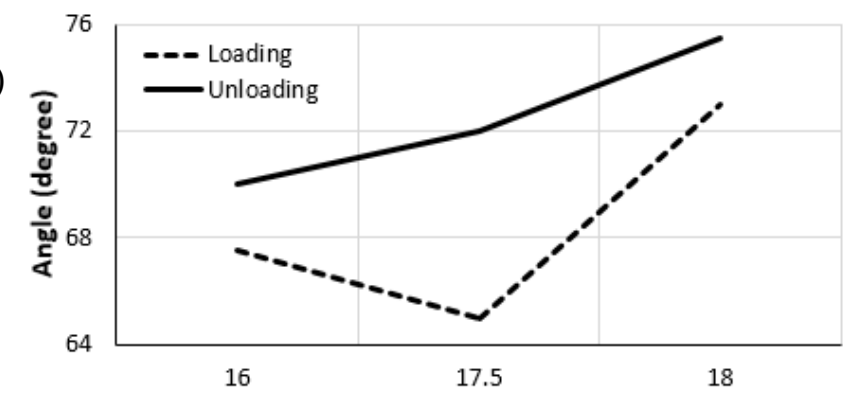

(B)

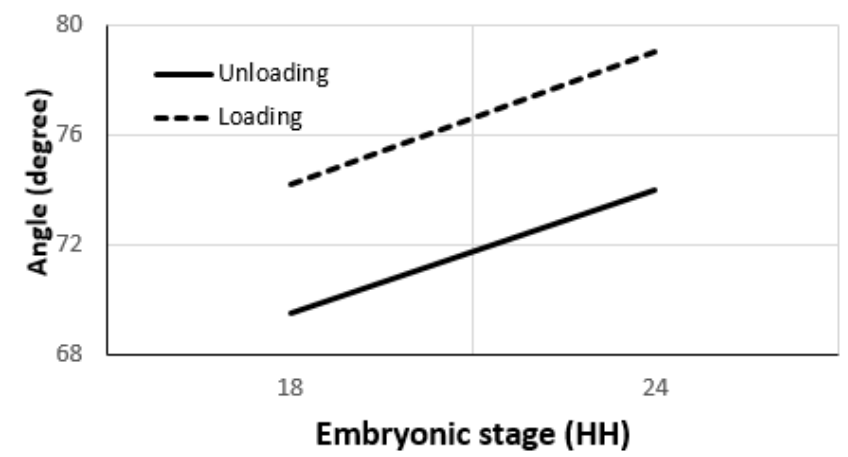

Figure 4. Changes in the effective opening angles of chick embryo arteries during early development are plotted. (A). Opening angle for vitelline arteries at stages HH16, HH17.5, and HH19 during loading and unloading conditions. (B). Opening angles for IVth right aortic arch at stages $\mathrm{HH} 18$ and HH24. Plots represent typical data collected over 13 chick embryos. Opening angles were calculated in our lab using the methodology presented in [12] using OCT and servo-null pressure data.

Aortic Arch vessels: Vessel stiffness also increases for the IVth aortic arch from HH18 to HH24 (Figure 4). The effective angle is higher during the loading condition and agrees with the stiffness trend. Results indicate that the increase in axial residual stress for aortic arch vessels is much higher than the increase for the vitelline artery. The residual stress in axial direction at $\mathrm{HH} 24$ is almost twice the residual stress at $\mathrm{HH} 18$. While circumferential residual stress is $0.17 \mathrm{kPa}$ at $\mathrm{HH} 18$, it almost doubles and becomes $0.33 \mathrm{kPa}$ at stage 24 . Although the increase in radial direction is not as high as in other directions, there is about a $0.1 \mathrm{kPa}$ increase between the two stages studied [45].

Supplementary Figure S3 highlights that stress values are variable through the vessel wall and that the stress-strain relation is incremental. Both the vitelline artery and the aortic arch have the same characteristics in terms of residual stress distribution for loading and unloading conditions. Residual stress in the axial and radial directions increases from the 
inner vessel wall to the outer vessel wall, contrary to circumferential residual stress, which decreases.

\section{Stress Distribution and Anisotropy}

In the literature, ample information is provided for flow-induced wall shear stresses [76]; however, tissue stresses derived from Fung's equation are unique to the present review as these values require a comprehensive structural soft-tissue analysis. As a general trend, stress increases with the growth of the vessel, and the slope of the stress-strain curves indicates slight stiffening. For both the vitelline artery and the aortic arch, the slopes of the stress-strain curves are higher for embryos at the later stages of development. As the embryo develops, it has increased circumferential rigidity compared to younger embryos. The von Mises stress distribution through the vessel wall is similar for relatively close stages. It is lowest at the inner wall of the vessel and highest at the outer wall for both vitelline and aortic arch vessels.

Vitelline artery: The von Mises stress at HH16 lies in the range of 0.17 to $0.22 \mathrm{kPa}$ between embryos. For stages 17.5 and 19, the von Mises stresses are almost equal, in the range of 0.21 to $0.26 \mathrm{kPa}$. The von Mises stress is larger for loading than the unloading condition at all stages. Loading and unloading conditions have similar trends for von Mises stress values; however, HH19 has a higher von Mises stress than HH17.5.

Aortic arch vessels: At stage HH18, a large variation in stress values is recorded, ranging from 0.12 to $0.2 \mathrm{kPa}$ and from 0.2 to $0.28 \mathrm{kPa}$ for unloading and loading conditions, respectively. Stress values at $\mathrm{HH} 24$ are much higher than at $\mathrm{HH} 18$. The von Mises stress at $\mathrm{HH} 24$ lies in the range of 0.45 to $0.7 \mathrm{kPa}$.

\subsection{Large Animal Models}

For completeness, basic anatomical dimensions are first reported. In sheep, LV thickness at 80 days of gestation period is $2.2 \mathrm{~mm}$, while, at day 127, it increases to $3.1 \mathrm{~mm}$. When an artificial aortic banding was employed surgically, it was found that the thickness remains the same initially but increases significantly at later stages of embryonic development (7 $\mathrm{mm}$ at 140 days of gestation) [77]. The mitral valve diameter of the ovine fetus at 100 days of gestation is reported as $9.1 \mathrm{~mm}$, while the aortic valve aortic annulus is $6.44 \mathrm{~mm}$. An increase in the mechanical loading results in an increase in the mitral valve dimensions but a decrease in the aortic annulus [78].

Embryonic data on biomechanical properties of bovine and ovine cardiovascular components are limited. Despite the ample biomechanical data on mature porcine heart valves [28,79-82], limited embryonic studies have been conducted to our knowledge. Ovine arterial pressure at the fetal stage was measured for different gestational ages. While the mean aortic blood pressure in the first week of gestation is $2.5 \mathrm{mmHg}$ [78], 5 weeks after gestation, it reaches $25 \mathrm{mmHg}$. At 116 days of gestation, the fetal descending aortic blood pressure is $41.1 \mathrm{mmHg}[83,84]$ and the right-atrial pressure is $\sim 2 \mathrm{mmHg}, 115-121$ days after gestation [83]. At the same gestational age (fifth week of gestation), the descending aortic blood pressure was found to be $64 \mathrm{mmHg}$ [85]. The aortic pressure of the ewe was found to range between 39.2 and $41.0 \mathrm{mmHg}, 126$ days after gestation. Mean arterial pressure (MAP) remains nearly constant as the embryo develops; however, if there is an increased systolic load (40 $\mathrm{mmHg}$ for 8 days), the mean arterial pressure increases to $63 \mathrm{mmHg}$ in 8 days [86]. A study conducted in 1989 measured the fetal blood pressure in ovine models to be $\sim 44 \mathrm{mmHg}$ [87], but no stage information was provided.

In [13], fetal and adult mitral valves were compared, where the maximum stress was observed to be $0.36 \mathrm{MPa}$ for fetal porcine mitral valves (third trimester) and $1.48 \mathrm{MPa}$ for 10 day old porcine mitral valves (Table 4). As the fetus develops, the thickness, the modulus of elasticity, and the stresses increase, as presented in Table 4, correlated with increased collagen content [13].

Cellular-level mechanical characteristics have been reported for large animals in the literature. Mononucleated and binucleated myocytes exhibit different lengths in ovine 
fetuses. At 135 days of gestation, mononucleated monocytes are 65 microns in LV and 69 microns in RV, with a width of 12 and 13 microns, respectively. Binucleated myocytes, on the other hand, have a length of 84 microns in LV and 92 microns in RV with a similar width to mononucleated myocytes [77]. Cardiomyocytes are generally unaffected by a reduction of load, but hyperplastic growth is affected by a reduced load in developing fetal hearts, as shown by a study conducted over a 100 day gestation period [78].

Table 4. Summary of the material properties for swine, rat, and Xenopus models during embryonic development. Embryonic stages for mice are recorded using the ED scale (embryonic day). ED0 is the day of fertilization, followed by ED1, ED2, etc. Similarly, for Xenopus, a scale measuring the number of hours post fertilization is used. As a general reference, CS is also provided. LV: left ventricle, RV: right ventricle, CS: Carnegie stage, ECG: electrocardiography, hpf: hours post fertilization.

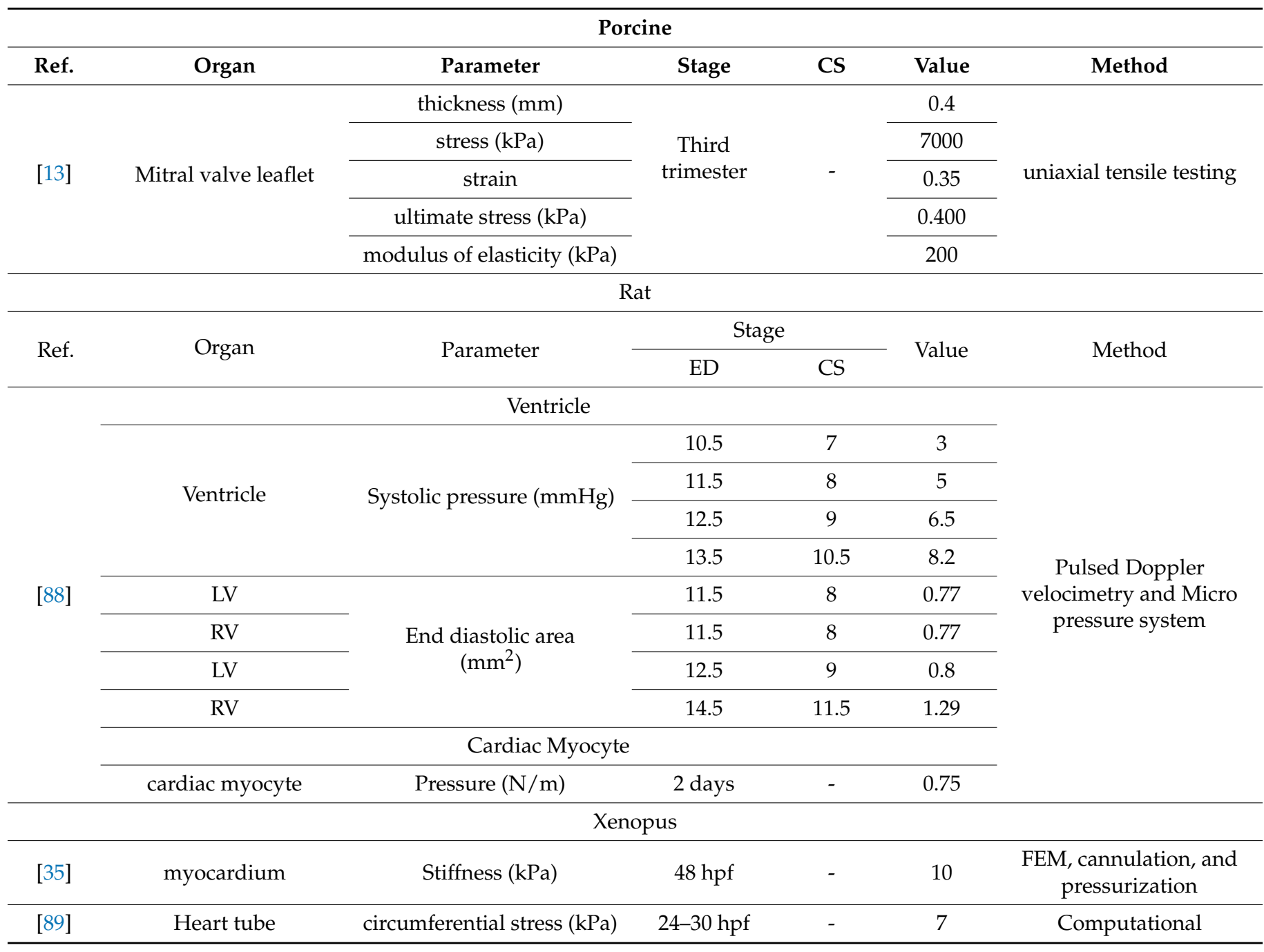

\subsection{Human Embryonic Development}

A reasonable estimate of human embryonic vascular properties can be obtained from umbilical vein and arteries. Maximum strain and stress values of the umbilical vein are 6 and 2.85 MPa, respectively [3]. The Young's modulus and maximum stress were calculated to be 2.18 and $6.01 \mathrm{MPa}$, respectively. Since the umbilical tissue is anisotropic, an average global strain value is calculated over the complete region, which peaked at $-14.4 \%$ for RV and $-13.8 \%$ for LV [90]. As the fetus ages, the peak strain reduces. For instance, the LV strain increases from $-13.8 \%$ in the first trimester to $-10.8 \%$ in the second trimester. It is 
also observed that the LV strain is higher than the RV strain in the first trimester, but the RV strain is higher in the second trimester.

Throughout gestation, the global longitudinal strain decreases while the strain rates remain unchanged. The LV attains a higher strain value than RV with a mean value of $28 \%$ and $26 \%$, respectively. The globally averaged longitudinal strain rate is 3.12 and 3.37 for RV and LV, respectively. A linear relationship can be developed between the gestational age and maximum strain [38].

Stress-strain characteristics measured in the radial direction for the umbilical vein show that, with the increase in artery wall thickness, the radial tensile strength increases until $750 \mu \mathrm{m}$, where the corresponding tensile strength is $7.5 \mathrm{~N}$ (Table 5) [42]. Similarly, the strength at $250 \mu \mathrm{m}$ is $6 \mathrm{~N}$, which implies that a lower thickness corresponds to lower stresses. Longitudinal tensile strength shows the same trend between 250 and $750 \mu \mathrm{m}$ with values ranging from 9 to $21 \mathrm{~N}$.

Another measure for estimating the material properties is by comparing the point of failure. In uniaxial or biaxial tensile testing, the material is stretched until failure which gives insight into the strength, elasticity, and stiffness of the material. Failure is caused either by direct and known stresses (primary failure) or by indirect, unknown stresses in the environment (secondary failure), both of which contribute to understanding the viscoelastic properties of the material. As an example, the umbilical cord consists of a component called the ringlet, as investigated by Rodriguez et al. [42]. Ringlet secondary failure occurs at a stress value of $0.5 \mathrm{MPa}$ and remains constant as the thickness increases and the embryo develops However, the ringlet primary failure occurs at a higher stress value (2.1 $\mathrm{MPa})$ for a lower umbilical arterial thickness and at a lower stress value $(\sim 0.4 \mathrm{MPa})$ as the thickness increases to $1000 \mu \mathrm{m}$. Similarly, longitudinal failure is highest at $250 \mu \mathrm{m}$ at $3.4 \mathrm{MPa}$ and lowest at $1000 \mu \mathrm{m}$. This shows that, as the embryo develops, it becomes stiffer and fails under lower stress values (Table 5).

The longitudinal tensile strength of the umbilical artery is the greater than the circumferential values (Table 5). The suture retention strength, as shown by Rodriguez et al., of the umbilical artery is highest $(1.75 \mathrm{~N}$ at $1000 \mu \mathrm{m})$ and increases with increased thickness, as expected. Burst pressure evaluates the ability of a vessel to withstand high blood pressures. For the umbilical artery, the highest burst pressure is sustained at $1000 \mu \mathrm{m}$ wall thickness, with a value of $\sim 1500 \mathrm{mmHg}$ [42]. Although the ability of the artery to withstand high pressure increases with thickness of the vessel, it decreases at a thickness of 750 microns to a value of $1250 \mathrm{mmHg}$. Umbilical cord arteries, however, were surprisingly found not to have any significant changes in the mechanical properties with an increase in gestational age [1]. Umbilical strain is a measure of deformability of the artery without any permanent deformation with respect to the original length. Although the strain increases with time, it is highest at the 30 th week with a value of 1.52 [1].

Table 5. Basic properties of human cardiovascular components at different gestational ages. Clinical measurement techniques and clinical image modalities are generally employed for data acquisition.

\begin{tabular}{|c|c|c|c|c|c|c|}
\hline Ref. & Organ & Parameter & Type & Stage (Weeks) & Value & Method \\
\hline \multicolumn{7}{|c|}{ Myocardium } \\
\hline \multirow{4}{*}{ [90] } & \multirow{4}{*}{ myocardium } & \multirow{4}{*}{ strain (\%) } & RV global & \multirow{4}{*}{ 1st trimester } & 14.4 & \multirow{4}{*}{$\begin{array}{l}\text { Uniaxial tensile } \\
\text { testing, FEM, } \\
\text { and ECG }\end{array}$} \\
\hline & & & LV global & & 13.8 & \\
\hline & & & RV regional & & 13.9 & \\
\hline & & & LV regional & & 13 & \\
\hline
\end{tabular}


Table 5. Cont.

\begin{tabular}{|c|c|c|c|c|c|c|}
\hline Ref. & Organ & Parameter & Type & Stage (Weeks) & Value & Method \\
\hline \multicolumn{7}{|c|}{ Ventricle } \\
\hline \multirow{9}{*}{ [38] } & $\mathrm{LV}$ & & \multirow{6}{*}{ global } & $16-21$ & 28.6 & \multirow{9}{*}{ ECG } \\
\hline & $\mathrm{LV}$ & & & $22-27$ & 27.47 & \\
\hline & $\mathrm{LV}$ & & & $28-38$ & 26.61 & \\
\hline & $\mathrm{RV}$ & & & $16-21$ & 27.79 & \\
\hline & RV & strain (\%) & & $22-27$ & 26.48 & \\
\hline & RV & & & $28-38$ & 24.72 & \\
\hline & $\mathrm{LV}$ & & \multirow{3}{*}{ systolic } & 21 & -15 & \\
\hline & $\mathrm{LV}$ & & & 28 & -25 & \\
\hline & $\mathrm{LV}$ & & & 34 & -35 & \\
\hline \multicolumn{7}{|c|}{ umbilical vein } \\
\hline \multirow{4}{*}{ [3] } & \multirow{4}{*}{ umbilical vein } & strain & \multirow{2}{*}{$\begin{array}{l}\text { derived from true } \\
\text { stress and/or strain }\end{array}$} & \multirow{4}{*}{-} & 4.1 & \multirow{4}{*}{$\begin{array}{c}\text { FEM and } \\
\text { uniaxial tensile } \\
\text { testing }\end{array}$} \\
\hline & & elastic modulus (MPa) & & & 4.5 & \\
\hline & & stress $(\mathrm{kPa})$ & $\max$ & & 6000 & \\
\hline & & strain & $\max$ & & 0.9 & \\
\hline & & & umbilical artery & & & \\
\hline \multirow{8}{*}{ [1] } & \multirow{13}{*}{ umbilical artery } & & & 25 & 57.89 & \multirow{13}{*}{$\begin{array}{l}\text { uniaxial tensile } \\
\text { testing and } \\
\text { scanning } \\
\text { electron } \\
\text { microscope }\end{array}$} \\
\hline & & stiffness (kPa) & & $26-30$ & 55.51 & \\
\hline & & Sliminess (KI d) & & $31-35$ & 76.53 & \\
\hline & & & & $36-40$ & 80.83 & \\
\hline & & & & 25 & 1.33 & \\
\hline & & strain & & $26-30$ & 1.52 & \\
\hline & & & & $31-35$ & 1.39 & \\
\hline & & & & $36-40$ & 1.41 & \\
\hline \multirow{5}{*}{ [42] } & & burst pressure $(\mathrm{kPa})$ & & - & 200 & \\
\hline & & strength $(\mathrm{N})$ & suture retention & - & 1.75 & \\
\hline & & stress $(\mathrm{kPa})$ & & - & 3500 & \\
\hline & & strength $(\mathrm{N})$ & longitudinal tensile & - & 21 & \\
\hline & & strength $(\mathrm{N})$ & radial tensile & - & 8 & \\
\hline \multicolumn{7}{|c|}{ Aorta } \\
\hline \multirow{3}{*}{ [39] } & \multirow{3}{*}{ aorta } & \multirow{3}{*}{ Stiffness index } & \multirow{3}{*}{ aortic compliance } & 25 & 0.7 & \multirow{3}{*}{$\begin{array}{l}\text { Doppler flow } \\
\text { profile and ECG }\end{array}$} \\
\hline & & & & 30 & 0.5 & \\
\hline & & & & 35 & 0.25 & \\
\hline \multicolumn{7}{|c|}{ Valves } \\
\hline \multirow{2}{*}{ [91] } & aortic valve & \multirow{2}{*}{ Elastic Modulus (kPa) } & & \multirow{2}{*}{21} & $4-5$ & Micro \\
\hline & Pulmonary valve & & & & $3-4$ & indentation \\
\hline & & hum & embryonic stem cells & & & \\
\hline & & & membrane stress & & 0.0013 & \\
\hline [37] & $\mathrm{hECS}$ & cardiomyente (kPa) & elastic modulus & _- & 0.0056 & optical \\
\hline$[3 /]$ & $\mathrm{hESC}$ & caraiomyocyte (kía) & membrane stress & & 0.0005 & stretching \\
\hline & & & elastic modulus & & 0.014 & \\
\hline
\end{tabular}




\subsection{Small Animal Models}

For mice, the stages of embryonic development are defined in embryonic days (ED). Experiments conducted by Ishiwata et al. [88] for the end-diastolic area showed that the values increase as the embryo develops. At embryonic day 11.5 (ED11.5), the area of the LV and $\mathrm{RV}$ was found to be $0.77 \mathrm{~mm}^{2}$. The area increased from $0.8 \mathrm{~mm}^{2}$ at ED 12.5 to $1.29 \mathrm{~mm}^{2}$ at ED 14.5 [88].

Nonlinearity in the LV stiffness trend due to preconditioning behavior of resting myocardium is explained by strain softening [92]. Wistar-Hannover rats showed lower circumferential strain $(-24.8 \%)$ than longitudinal strain $(-19.3 \%)$. Pulmonary congestion resulted in higher longitudinal strain at about $-10.1 \%$ and $-13.8 \%$ circumferentially. Global strain rate showed a similar trend with circumferential and longitudinal strain rates of $-4 \mathrm{~s}^{-1}$ and $-4.7 \mathrm{~s}^{-1}$, respectively [93].

Alterations in myocardial stress and strain at septal walls reduce the functional capacity of the ventricle. These abnormal changes may indicate the presence and severity of CHD, as seen in Table 6. For example, myocardial strain levels for a heart with fibrotic infarction progressively increase to nearly twice the strain values of a healthy heart [14]. Table 6 reviews additional clinical cardiac abnormalities with significance in material properties.

Table 6. General material property trends for selected cardiac malformations. CTB: conotruncal banding, LV: left ventricle, RV: right ventricle, CHD: congenital heart disease.

\begin{tabular}{ccc}
\hline Fetal Malformation & Change in Material Property & Ref. \\
\hline Fibrotic infarction & Doubled ventricular strain and increased myocardial stress. & [14] \\
\hline Conotruncal defects & Increased ventricular pressure & Higher longitudinal strain compared to the circumferential direction \\
\hline pulmonary congestion & Increased stiffness & Reduced strains in LV \\
\hline Hypertensive heart & Reduced systolic strains & {$[15]$} \\
\cline { 2 - 3 } & Increased ventricular wall thickness and stiffness \\
\hline Hypertrophy & Higher end diastolic stresses and cross-fiber stresses \\
\hline aneurysm & Enlargement and weakening of heart muscles \\
\hline Marfan syndrome & Enlargement of aorta \\
\hline Loeys-Dietz syndrome & Reduced elasticity, strength, and stiffness of the aortic vessels \\
\hline Ehlers-Danlos syndrome & Decreased ventricular pressure with compact and thinner myocardium \\
\hline Fibrotic infarction & [18] & [19] \\
\hline
\end{tabular}

Stresses were calculated for various cardiac regions, and it was seen that, when a fixed load is applied during uniaxial tensile testing, the circumferential, longitudinal, and radial stresses increase from 2.8 to $18.2 \mathrm{kPa}, 1.5$ to $9.7 \mathrm{kPa}$, and $0.1 \mathrm{kPa}$ to $0.6 \mathrm{kPa}$, respectively. The increase in stress is 10-fold. Corresponding strain levels also increase from 0.100 to 0.138 . RV deformations affect the LV diastolic mechanism and LV passive inflation. For both ventricles, stresses vary for the basal, equatorial, and apical and for the anterior, lateral, posterior, and septum regions. The highest stress is observed at the lateral equatorial region, reaching $3 \mathrm{kPa}$ [98].

\subsection{Mechanogenetic Regulation and Response}

Vascular material properties are regulated through specific genetic pathways. In particular, the timescales involved in this tightly coupled system are not well established. In addition to the direct synthesis of matrix constituents, genes program material properties through biochemical means such as paracrine pathways to ensure that the cardiovascular system remains in its optimal condition. Cardiac looping and left-right asymmetry in ventricles are physiological features that are regulated by genes and play a role in the CHD 
and cardiac development [99]. Cyclic strain also plays a major role in cardiomyogenic differentiation of rat bone marrow stem cells as opposed to shear stress, and it increases cardiomyocyte-related markers [100].

The effect of shear stress has been studied in avian and mice embryos in the cardiovascular systems (umbilical arteries, and veins). It was observed that the gene expression profiles are altered by a shear stress-initiated release of prostacyclin and NO. Activated by changes in wall shear stress values [21,22,101-106], well-established mechanosensitive genes such as ET-1, NO, and eNOS are integral parts of the cardiovascular system. Growth hormone ET-1, for instance, is involved in vasoconstriction, and NO is involved in vasodilation [21], while KLF-2 is involved in vasculogenesis and angiogenesis [107]. Fluid shear stress is known to suppress endothelin 1 mechanosensitive genes [108]. ET-1 interacts with elastin and alters calcium content [109-112]. Elastin (Eln) in porcine embryos was evaluated, and its expression intensity was 42 in the third trimester. Despite the obvious differences in mitral and aortic valves following birth, these valves are identical in their genetic composition at the embryonic and fetal stages [113].

It is well established that arterial endothelial NO production and eNOS expression are controlled by shear stress [106]. KLF-2 expression is highest where the stress is highest. When the regulation of these genes is affected due to an inconsistency in the shear stress levels, the genetic risk factors for CHD increase, as in the NOS expression regulated by fluid shear stress [22,101]. Another study showed that the nature of force experienced influences the response of the endothelial genes [114]. Shear stress increases eNOS mRNA levels and cyclic stretch affects ET-1 mRNA levels. When applied simultaneously, the response of genes is significantly different from the individual effects.

Cardiac load also affects several genes and their expression levels. When the cardiac load is increased, a significant difference is observed in the levels of Notch-1, TGF-2, Wnt-2b, and BMP-1. For both mitral and aortic valves, these levels decline with the increase in load. Similarly, mRNA expression levels of elastin, type I collagen, and versican all decrease [115]. Cardiac malformations are known to depend on TGF $\beta$ levels [116] and shear stress affects KLF2 levels by activating the TGF $\beta$ / ALK5 signaling pathway $[103,116,117]$. In particular, miR-1 affects structural remodeling of the heart [118]. miR-128 regulates hyperplasia and Islet1 expression levels during cardiac regeneration [119]. Other genes such as Cadherin-11 and Fibirillin-1 affect thickness and arterial diameter. These genes also affect the calcification pathway in the cardiovascular system [120,121]. AGTR1, ACE, AGT, CYP11B2, and ADD1 are some factors that affect elasticity in the system [105]. MMP3, MMP9, and M235T affect the stiffness and impedance through the activation of factors. NFKB, MAP Kinase, MEK, and PI-3K affect the shear stress response in the system [31,122,123]. SMAD6 is indirectly associated with the thickness of the aorta despite not being mechanosensitive [124]. As such, abnormalities in SMAD levels can cause thoracic aortic aneurysms. The plasticity index is monitored by PKP2 in cardiac cells. Stress also activates IL33, which plays a role in end-stage cardiac failure $[125,126]$. RAAS is another important gene which is reported to influence the stiffness of the cardiac vessels [127]. Table 7 presents the mechanosensitive and mechanoresponsive genes that have been studied in literature. 
Table 7. Mechanical property phenotypes and the response of mechanosensitive genes that play a critical role in structural cardiovascular development are summarized. Mechanosensitive genes are activated as a response to mechanical changes, while mechanoresponsive genes cause a mechanical change in the tissues. The effect of abnormal gene/pathway signaling is associated with cardiovascular system defects. WT: wild type, KO: knockout. KI: knock-in, M: mutant, R: review.

\begin{tabular}{|c|c|c|c|c|c|c|c|}
\hline Gene & Organ & Defect & Mechanosensitive & Indirect Alterations & $\begin{array}{l}\text { Mechanical Properties } \\
\text { Altered }\end{array}$ & Ref. & GP \\
\hline \multirow{4}{*}{ Fibulin 4 coded by EFEMP2 gene } & \multirow{4}{*}{$\begin{array}{l}\text { Large conduit arterial walls in } \\
\text { mice }\end{array}$} & \multirow{4}{*}{$\begin{array}{l}\text { Ascending Aortic } \\
\text { aneurysms, loose skin, } \\
\text { bent forelimb, tortuous } \\
\text { artery, and pulmonary } \\
\text { emphysema }\end{array}$} & \multirow{4}{*}{$\begin{array}{l}\text { Interacts with } \\
\text { elastin directly }\end{array}$} & \multirow{4}{*}{-} & \multirow{4}{*}{ Alters elastin, binds to calcium } & [109] & KI \\
\hline & & & & & & [110] & $\mathrm{KO}$ \\
\hline & & & & & & [111] & KI \\
\hline & & & & & & [112] & $\mathrm{KO}$ \\
\hline Endothelin 1 (ET1) & $\begin{array}{l}\text { Human umbilical vein } \\
\text { endothelial cells }\end{array}$ & & $\begin{array}{l}\text { Reacts directly to } \\
\text { shear stress and } \\
\text { cyclic stretch }\end{array}$ & & Shear stress and cyclic stretch & [114] & WT \\
\hline \multirow[t]{2}{*}{ Elastin coded by Eln } & \multirow[t]{2}{*}{ Mouse aortic walls } & \multirow{2}{*}{$\begin{array}{l}\text { Arterial stenosis, } \\
\text { hypertension }\end{array}$} & \multirow[t]{2}{*}{ Direct interaction } & \multirow[t]{2}{*}{-} & \multirow{2}{*}{$\begin{array}{l}\text { Alters elastic fibers, thickening } \\
\text { and arterial tortuosity }\end{array}$} & {$[128]$} & $\mathrm{M}$ \\
\hline & & & & & & [129] & $\mathrm{KO}$ \\
\hline miR-1 & $\begin{array}{l}\text { Cardiac contractile function in } \\
\text { mice }\end{array}$ & $\begin{array}{l}\text { Damage in sarcomere } \\
\text { assembly }\end{array}$ & - & $\begin{array}{c}\text { Targets UTRs of } \\
\text { MYLK3, CALM1, and } \\
\text { CALM2 }\end{array}$ & $\begin{array}{l}\text { Affects structural remodeling } \\
\text { of the heart }\end{array}$ & [118] & $\mathrm{KO}$ \\
\hline VEGF & Endothelial cells & Matrix stiffens & - & $\begin{array}{l}\text { In turn effects MMP } \\
\text { activity }\end{array}$ & Stiffness, intima & {$[104,130]$} & $\mathrm{M}$ \\
\hline \multirow{2}{*}{ Cadherin-11 } & \multirow{2}{*}{$\mathrm{ECM}$ in aorta in mice } & \multirow{2}{*}{$\begin{array}{l}\text { Cardiac dysfunction in } \\
\text { valves }\end{array}$} & \multirow{2}{*}{-} & \multirow{2}{*}{$\begin{array}{l}\text { Reduced Sox9 activity, } \\
\beta 1 \text { integrin expression, } \\
\text { and RhoA-GTP }\end{array}$} & \multirow{2}{*}{$\begin{array}{c}\text { Increases thickness and alters } \\
\text { stress fibers, causes } \\
\text { calcification }\end{array}$} & [120] & $\mathrm{KO}$ \\
\hline & & & & & & [121] & KI \\
\hline \multirow{2}{*}{$\begin{array}{l}\text { NOS-3, KLF-2, ET-1 (can be altered by } \\
\text { changing trichloroethylene doses) [131] }\end{array}$} & \multirow{2}{*}{$\begin{array}{l}\text { Chick, bovine, mice embryonic } \\
\text { cardiovascular system }\end{array}$} & & \multirow{2}{*}{$\begin{array}{l}\text { Shear stress } \\
\text { induced }\end{array}$} & \multirow{2}{*}{$\begin{array}{l}\text { KLF2 indirectly } \\
\text { activated by TGF } \beta\end{array}$} & \multirow{2}{*}{ Activated by shear stress } & [104] & $\mathrm{M}$ \\
\hline & & & & & & {$[101,106]$} & WT \\
\hline TGF $\beta$ & $\begin{array}{l}\text { Embryonic endothelial cells } \\
\text { (human) }\end{array}$ & Cardiac malformations & $\begin{array}{l}\text { Activated by } \\
\text { shear activities }\end{array}$ & $\begin{array}{l}\text { Can be affected by } \\
\text { fibulin deficiency }\end{array}$ & $\begin{array}{c}\text { Directly activated by shear } \\
\text { stress }\end{array}$ & {$[103,116,117]$} & WT, M \\
\hline $\mathrm{ROBO} 4$ & $\begin{array}{l}\text { Bicuspid aortic valve and } \\
\text { thoracic aortic }\end{array}$ & CHD and aneurysm & & & & [132] & $\mathrm{KO}$ \\
\hline Notch1 & Mice aorta & $\begin{array}{l}\text { Ascending Aortic } \\
\text { Aneurysm }\end{array}$ & & & & [133] & $\mathrm{KO}$ \\
\hline AGTR1, ACE, AGT, CYP11B2, ADD1 & Human artery, vascular & $\mathrm{CHD}$ & & Indirect association & Elasticity & [105] & $\mathrm{R}$ \\
\hline
\end{tabular}


Table 7. Cont.

\begin{tabular}{|c|c|c|c|c|c|c|c|}
\hline Gene & Organ & Defect & Mechanosensitive & Indirect Alterations & $\begin{array}{l}\text { Mechanical Properties } \\
\text { Altered }\end{array}$ & Ref. & GP \\
\hline MMP3, MMP9, M235T & Human artery, mice vascular & CHD & & Indirect association & Stiffness and impedance & {$[105,134]$} & $\mathrm{R}$ \\
\hline NFKB & Vascular response in mice & & Direct & & Activated by shear stress & [123] & $\mathrm{R}$ \\
\hline MAP Kinase & Blood vessels & & $\begin{array}{l}\text { Shear activated or } \\
\text { stretch activated }\end{array}$ & & Shear stress and stretch & [8] & \\
\hline MEK, PI-3K & $\begin{array}{l}\text { Ovine fetoplacental artery } \\
\text { endothelial cells }\end{array}$ & & & $\begin{array}{c}\text { Activated by eNOS } \\
\text { (indirectly activated by } \\
\text { stress) }\end{array}$ & Shear stress & [31] & WT \\
\hline SMAD6 & $\begin{array}{l}\text { Thoracic aorta and bicuspid } \\
\text { valve in humans }\end{array}$ & Thoracic aortic aneurysm & & Indirect & Thickness & [124] & M \\
\hline PKP2 & Cardiac cells inMice & & & $\begin{array}{l}\text { Indirect, affects } \\
\text { miR200b first }\end{array}$ & $\begin{array}{l}\text { Knockdown causes reduced } \\
\text { stress and work of } \\
\text { detachment, increases } \\
\text { plasticity index }\end{array}$ & [135] & $\mathrm{KO}$ \\
\hline \multirow{2}{*}{ IL33 } & \multirow{2}{*}{$\begin{array}{l}\text { Myocardium in mice and } \\
\text { humans }\end{array}$} & \multirow{2}{*}{ Failing heart } & \multirow{2}{*}{$\begin{array}{l}\text { Induced by } \\
\text { mechanical stress }\end{array}$} & & \multirow{2}{*}{ Stress } & [126] & $\mathrm{KO}$ \\
\hline & & & & & & [125] & WT \\
\hline miR-128 & Cardiac ECM & Hyperplasia & & $\begin{array}{l}\text { Regulates hyperplasia } \\
\text { and Islet1 }\end{array}$ & & [119] & $\mathrm{KO}$ \\
\hline RAAS & Cardiac vessels & Vascular hypertrophy & & Regulates stiffness & Stiffness & [127] & $\mathrm{R}$ \\
\hline
\end{tabular}




\section{Discussion}

Among the several vascular components reviewed here, the myocardium has the highest stress concentrations at end-systole, while the residual stresses are responsible for further augmenting this stress level. At the early embryonic timepoint, the cardiac jelly present between the myocardium and the endocardium helps to enhance systole and diastole. Similarly, the stresses of the RV and LV are nonuniformly distributed at later stages [9]. As the embryo matures from HH16 to HH18, a $0.01 \mathrm{~mm}^{2}$ increase in the cross-sectional area of the tubular ventricle is observed. The LV cross-sectional area also increases from $\mathrm{HH} 27$ to $\mathrm{HH} 31$, together with the ventricular strain due to increased stress levels [67]. It was found that the LV is always thicker than the RV [63]. Similarly, ventricular length increases with development. The strain data show a similar trend for the ventricles [30]. Later stages experience lower stress levels in the ventricles between $\mathrm{HH} 21$ and HH27. It was also observed that circumferential strain is always higher than longitudinal strain [68]. RV has lower myocardial stiffness than the left in all cases and in all directions [65]. Compact layer thickness also increases as the chick embryo matures. This layer carries the highest stresses corelated with growth. Systolic pressure is significantly lower than diastolic pressure. Likewise, diastolic stiffness is also higher than systolic values. However, the diastolic stiffness reduces as the embryo develops [9,68,69].

Strain energy for developing septal heart valve leaflets increases as the embryo develops. The superior cushion of the heart valve leaflets experiences higher strain energy than the inferior. Myocardial mural strain energy also shows a similar increase with the embryonic development.

Longitudinal strength and suture retention strength for the umbilical arteries increase uniformly with the increase in thickness, while burst pressure increases nonuniformly, as shown by Rodrigue et al. [42]. It is also seen that, as thickness increases, primary and longitudinal failure occur at lower stress levels unlike secondary failure, which remains nearly constant.

While the mechanical properties of disease states were not the focus of this review, it is well established that the symptoms of fibrotic infarction include nearly doubled ventricular strain and increased myocardial stress [14]. Mechanical interventions and diseases can lead to similar effects. For example CTB shows increased pressure in the LV [19]; thus, we can conclude that conotruncal cardiac anomalies also cause increased pressure in the LV. As such, pulmonary congestion occurs when the longitudinal strain is higher than circumferential strain. Reduced strains in LV [16] and systolic strains [15], as well as increased stiffness [16], cause a hypertensive heart. Hypertrophy occurs when there is an increased ventricular wall thickness and stiffness [17].

Likewise, CHDs may be initiated when there are reduced strains in the ventricles; higher end-diastolic stresses and altered cross-fiber stresses can cause vascular aneurysms [18]. For example, verapamil suffusion occurs with decreased pressure in the ventricles with a compact and thinner myocardium [19]. In a recent study, the effects of various disease features on functionality of the heart were modeled [55]. These studies indicated that LV hypertrophy significantly increased LV pressure, strain, and stroke volume, leading to high mitral regurgitation valve velocities.

In this review, while the cellular-level bulk material properties were only briefly included, complex molecular structures and the material property changes during cellular differentiation deserve dedicated review efforts. For example, cardiomyocytes have a significantly lower value of strength and elastic modulus than hESCs (human embryonic stem cells), showing that the cardiomyocytes lose their strength and elasticity during their specialization, as summarized in Table 5. 


\section{Conclusions}

Material properties of tissues, during development, growth, and disease states, affect how these tissues respond to mechanical forces and their microenvironment. In order to understand and control the vascular structure, the complexity of the cardiovascular system justifies an integrated approach that couples mechano-genetic characteristics with the material properties. Model organisms that possess a biventricular cardiovascular system broadly resemble the human circulation. Due to ethical reasons and experimental challenges, inferences from these model systems are informative for the development of the human heart. Therefore, the present study provides a look-up table of the embryonic material properties across species where human vascular data can be approximately referenced. As such, overall strain and stiffness values tend to increase with age of the developing embryo. It is also observed that the strain values for the LV are consistently higher than for the RV across species. Similarly, ventricular, pressures and size also continue to increase with age. While there is an increase in size, RV continues to grow faster than the LV, maintaining a larger ventricular size and thickness throughout the growth [88]. It is also important to note that the radial strength is generally considerably lower than the longitudinal strength in vascular vessels (Table 5). Genetic signaling also interacts with the mechanical characteristics through the paracrine pathways. Alternatively, studying the genetic patterns can explain changes in the material properties and the body's reaction to these changes. The review also evaluated the consequences of malfunctioning genes and/or abnormal mechanical loading changes and their role in causing CHDs. It is hoped that these inferences concatenate the anatomical, genetic, and mechanical understanding of the heart and further inspire new interdisciplinary studies of complex cardiovascular system.

Supplementary Materials: The following supporting information can be downloaded at: https: / / www.mdpi.com/article/10.3390/jcdd9020064/s1, Figure S1: Computed Cauchy residual stress values for the vitelline vessels in chick embryo at HH16, HH17.5 and HH19 during physiologic loading and unloading conditions. Representative of one of the 8 embryos. calculated using the methodology presented in [12]; Figure S2: Computed Cauchy residual stress values for the chick embryo fourth aortic arch at $\mathrm{HH} 18$ and $\mathrm{HH} 24$ during physiologic loading and unloading conditions. Representative of one of the 5 embryos. calculated using the methodology presented in [12]; Figure S3: Stress strain relation for TOP: the vitelline vessels in chick embryo at HH16, HH17.5 and HH19 during physiologic loading and unloading conditions. Representative of one of the 8 embryos. BOTTOM: fourth aortic arch in chick embryo at HH18 and HH24 during physiologic loading and unloading conditions. Representative of one of the 5 embryos.

Author Contributions: Conceptualization, K.P. and H.B.S.; methodology and experiments, S.D., S.S.L. and H.B.S.; literature review and comparative analysis, K.P. and H.B.S.; manuscript preparation, all authors. All authors have read and agreed to the published version of the manuscript.

Funding: This study was funded by the TUBITAK 120C139 grant.

Institutional Review Board Statement: Not applicable.

Informed Consent Statement: Not applicable.

Data Availability Statement: All data acquired that support the findings of this study are available on request from the corresponding author.

Acknowledgments: We would like to express our gratitude to Erhan Ermek for his support and contribution in assisting data collection during the experiments.

Conflicts of Interest: The authors declare no conflict of interest. 


\section{References}

1. Nye, K.S.; Esplin, M.S.; Monson, K.L. Umbilical cord artery mechanical properties at various gestational ages. Am. J. Perinatol. 2015, 32, 263-270. [CrossRef] [PubMed]

2. $\quad$ Li, P.; Liu, A.; Shi, L.; Yin, X.; Rugonyi, S.; Wang, R.K. Assessment of strain and strain rate in embryonic chick heart in vivo using tissue Doppler optical coherence tomography. Phys. Med. Biol. 2011, 56, 7081-7092. [CrossRef] [PubMed]

3. Karimi, A.; Navidbakhsh, M.; Rezaee, T.; Hassani, K. Measurement of the circumferential mechanical properties of the umbilical vein: Experimental and numerical analyses. Comput. Methods Biomech. Biomed. Eng. 2015, 18, 1418-1426. [CrossRef] [PubMed]

4. Lucitti, J.L.; Tobita, K.; Keller, B.B. Arterial hemodynamics and mechanical properties after circulatory intervention in the chick embryo. J. Exp. Biol. 2005, 208, 1877-1885. [CrossRef]

5. Gjorevski, N.; Nelson, C.M. The mechanics of development: Models and methods for tissue morphogenesis. Birth Defects Res. C Embryo Today 2010, 90, 193-202. [CrossRef]

6. Forouhar, A.S.; Liebling, M.; Hickerson, A.; Nasiraei-Moghaddam, A.; Tsai, H.J.; Hove, J.R.; Fraser, S.E.; Dickinson, M.E.; Gharib, M. The embryonic vertebrate heart tube is a dynamic suction pump. Science 2006, 312, 751-753. [CrossRef]

7. Yang, M.; Taber, L.A.; Clark, E.B. A nonliner poroelastic model for the trabecular embryonic heart. J. Biomech. Eng. 1994, 116, 213-223. [CrossRef]

8. Yao, J.; Varner, V.D.; Brilli, L.L.; Young, J.M.; Taber, L.A.; Perucchio, R. Viscoelastic material properties of the myocardium and cardiac jelly in the looping chick heart. J. Biomech. Eng. 2012, 134, 024502. [CrossRef]

9. Taber, L.A.; Keller, B.B.; Clark, E.B. Cardiac mechanics in the stage-16 chick embryo. J. Biomech. Eng. 1992, 114, 427-434. [CrossRef]

10. Tobita, K.; Keller, B.B. Right and left ventricular wall deformation patterns in normal and left heart hypoplasia chick embryos. Am. J. Physiol. Heart Circ. Physiol. 2000, 279, H959-H969. [CrossRef]

11. Tobita, K.; Garrison, J.B.; Liu, L.J.; Tinney, J.P.; Keller, B.B. Three-dimensional myofiber architecture of the embryonic left ventricle during normal development and altered mechanical loads. Anat. Rec. A Discov. Mol. Cell. Evol. Biol. 2005, 283, 193-201. [CrossRef] [PubMed]

12. Donmazov, S.; Piskin, S.; Pekkan, K. Noninvasive in vivo determination of residual strains and stresses. J. Biomech. Eng. 2015, 137, 061011. [CrossRef] [PubMed]

13. Kasyanov, V.; Moreno-Rodriguez, R.A.; Kalejs, M.; Ozolanta, I.; Stradins, P.; Wen, X.; Yao, H.; Mironov, V. Age-related analysis of structural, biochemical and mechanical properties of the porcine mitral heart valve leaflets. Connect. Tissue Res. 2013, 54, 394-402. [CrossRef]

14. Zhuan, X.; Luo, X. Residual Stress Estimates from Multi-cut Opening Angles of the Left Ventricle. Cardiovasc. Eng. Technol. 2020, 11, 381-393. [CrossRef] [PubMed]

15. Nabati, M.; Namazi, S.S.; Yazdani, J.; Sharif Nia, H. Relation Between Aortic Stiffness Index and Distensibility with Age in Hypertensive Patients. Int. J. Gen. Med. 2020, 13, 297-303. [CrossRef] [PubMed]

16. Ishizu, T.; Seo, Y.; Kameda, Y.; Kawamura, R.; Kimura, T.; Shimojo, N.; Xu, D.; Murakoshi, N.; Aonuma, K. Left ventricular strain and transmural distribution of structural remodeling in hypertensive heart disease. Hypertension 2014, 63, 500-506. [CrossRef] [PubMed]

17. Vejdani-Jahromi, M.; Nagle, M.; Trahey, G.E.; Wolf, P.D. Ultrasound shear wave elasticity imaging quantifies coronary perfusion pressure effect on cardiac compliance. IEEE Trans. Med. Imaging 2015, 34, 465-473. [CrossRef]

18. Walker, J.C.; Ratcliffe, M.B.; Zhang, P.; Wallace, A.W.; Hsu, E.W.; Saloner, D.A.; Guccione, J.M. Magnetic resonance imaging-based finite element stress analysis after linear repair of left ventricular aneurysm. J. Thorac. Cardiovasc. Surg. 2008, 135, 1094-1102. [CrossRef]

19. Buffinton, C.M.; Faas, D.; Sedmera, D. Stress and strain adaptation in load-dependent remodeling of the embryonic left ventricle. Biomech. Model. Mechanobiol. 2013, 12, 1037-1051. [CrossRef]

20. Stekelenburg-de Vos, S.; Steendijk, P.; Ursem, N.T.; Wladimiroff, J.W.; Poelmann, R.E. Systolic and diastolic ventricular function in the normal and extra-embryonic venous clipped chicken embryo of stage 24: A pressure-volume loop assessment. Ultrasound Obstet. Gynecol. 2007, 30, 325-331. [CrossRef]

21. Groenendijk, B.C.; Hierck, B.P.; Gittenberger-De Groot, A.C.; Poelmann, R.E. Development-related changes in the expression of shear stress responsive genes KLF-2, ET-1, and NOS-3 in the developing cardiovascular system of chicken embryos. Dev. Dyn. 2004, 230, 57-68. [CrossRef] [PubMed]

22. Groenendijk, B.C.; Hierck, B.P.; Vrolijk, J.; Baiker, M.; Pourquie, M.J.; Gittenberger-de Groot, A.C.; Poelmann, R.E. Changes in shear stress-related gene expression after experimentally altered venous return in the chicken embryo. Circ. Res. 2005, 96, 1291-1298. [CrossRef] [PubMed]

23. Taber, L.A.; Voronov, D.A.; Ramasubramanian, A. The role of mechanical forces in the torsional component of cardiac looping. Ann. N. Y. Acad. Sci. 2010, 1188, 103-110. [CrossRef]

24. Wessels, A.; Markwald, R. Cardiac morphogenesis and dysmorphogenesis. I. Normal development. Methods Mol. Biol. 2000, 136, 239-259. [PubMed]

25. Davidson, L.A. Mechanical design in embryos: Mechanical signalling, robustness and developmental defects. Philos. Trans. $R$. Soc. Lond. B Biol. Sci. 2017, 372, 20150516. [CrossRef] [PubMed]

26. Schulze-Bauer, C.A.J.; Morth, C.; Holzapfel, G.A. Passive Biaxial Mechanical Response of Aged Human Iliac Arteries. J. Biomech. Eng. 2003, 125, 395-406. [CrossRef] 
27. Ferrara, A.; Morganti, S.; Totaro, P.; Mazzola, A.; Auricchio, F. Human dilated ascending aorta: Mechanical characterization via uniaxial tensile tests. J. Mech. Behav. Biomed. Mater. 2016, 53, 257-271. [CrossRef]

28. Ross, C.; Laurence, D.; Wu, Y.; Lee, C.-H. Biaxial Mechanical Characterizations of Atrioventricular Heart Valves. J. Vis. Exp. 2019, 9, e59170. [CrossRef]

29. Murdock, K.; Martin, C.; Sun, W. Characterization of mechanical properties of pericardium tissue using planar biaxial tension and flexural deformation. J. Mech. Behav. Biomed. Mater. 2018, 77, 148-156. [CrossRef]

30. Miller, C.E.; Wong, C.L.; Sedmera, D. Pressure overload alters stress-strain properties of the developing chick heart. Am. J. Physiol. Heart Circ. Physiol. 2003, 285, H1849-H1856. [CrossRef]

31. Li, Y.; Zheng, J.; Bird, I.M.; Magness, R.R. Mechanisms of shear stress-induced endothelial nitric-oxide synthase phosphorylation and expression in ovine fetoplacental artery endothelial cells. Biol. Reprod. 2004, 70, 785-796. [CrossRef] [PubMed]

32. Filas, B.A.; Xu, G.; Taber, L.A. Probing regional mechanical properties of embryonic tissue using microindentation and optical coherence tomography. Methods Mol. Biol. 2015, 1189, 3-16. [PubMed]

33. Smoljkic, M.; Vander Sloten, J.; Segers, P.; Famaey, N. Non-invasive, energy-based assessment of patient-specific material properties of arterial tissue. Biomech. Model. Mechanobiol. 2015, 14, 1045-1056. [CrossRef]

34. Joshi, S.D.; Kim, H.Y.; Davidson, L.A. Microscopy tools for quantifying developmental dynamics in Xenopus embryos. Methods Mol. Biol. 2012, 917, 477-493.

35. Gendernalik, A.; Zebhi, B.; Ahuja, N.; Garrity, D.; Bark, D., Jr. In Vivo Pressurization of the Zebrafish Embryonic Heart as a Tool to Characterize Tissue Properties During Development. Ann. Biomed. Eng. 2021, 49, 834-845. [CrossRef] [PubMed]

36. Teal, S.I.; Moore, G.W.; Hutchins, G.M. Development of aortic and mitral valve continuity in the human embryonic heart. Am. J. Anat. 1986, 176, 447-460. [CrossRef] [PubMed]

37. Tan, Y.; Kong, C.W.; Chen, S.; Cheng, S.H.; Li, R.A.; Sun, D. Probing the mechanobiological properties of human embryonic stem cells in cardiac differentiation by optical tweezers. J. Biomech. 2012, 45, 123-128. [CrossRef]

38. Clavero Adell, M.; Ayerza Casas, A.; Jimenez Montanes, L.; Palanca Arias, D.; Lopez Ramon, M.; Alcala Nalvaiz, J.T.; Samper Villagrasa, P. Evolution of strain and strain rate values throughout gestation in healthy fetuses. Int. J. Cardiovasc. Imaging 2020, 36, 59-66. [CrossRef]

39. Taketazu, M.; Sugimoto, M.; Saiki, H.; Ishido, H.; Masutani, S.; Senzaki, H. Developmental Changes in Aortic Mechanical Properties in Normal Fetuses and Fetuses with Cardiovascular Disease. Pediatr. Neonatol. 2017, 58, 245-250. [CrossRef]

40. Smoljkic, M.; Verbrugghe, P.; Larsson, M.; Widman, E.; Fehervary, H.; D’Hooge, J.; Vander Sloten, J.; Famaey, N. Comparison of in vivo vs. ex situ obtained material properties of sheep common carotid artery. Med. Eng. Phys. 2018, 55, 16-24. [CrossRef]

41. Van der Heiden, K.; Groenendijk, B.C.; Hierck, B.P.; Hogers, B.; Koerten, H.K.; Mommaas, A.M.; Gittenberger-de Groot, A.C.; Poelmann, R.E. Monocilia on chicken embryonic endocardium in low shear stress areas. Dev. Dyn. 2006, 235, 19-28. [CrossRef] [PubMed]

42. Rodriguez, M.; Juran, C.; McClendon, M.; Eyadiel, C.; McFetridge, P.S. Development of a mechanically tuneable 3D scaffold for vascular reconstruction. J. Biomed. Mater. Res. A 2012, 100, 3480-3489. [CrossRef] [PubMed]

43. Lin, I.E.; Taber, L.A. Mechanical effects of looping in the embryonic chick heart. J. Biomech. 1994, 27, 311-321. [CrossRef]

44. Disney, C.M.; Lee, P.D.; Hoyland, J.A.; Sherratt, M.J.; Bay, B.K. A review of techniques for visualising soft tissue microstructure deformation and quantifying strain Ex Vivo. J. Microsc. 2018, 272, 165-179. [CrossRef] [PubMed]

45. Lashkarinia, S.S.; Coban, G.; Ermek, E.; Celik, M.; Pekkan, K. Spatiotemporal remodeling of embryonic aortic arch: Stress distribution, microstructure, and vascular growth in silico. Biomech. Model. Mechanobiol. 2020, 19, 1897-1915. [CrossRef]

46. Xu, G.; Kemp, P.S.; Hwu, J.A.; Beagley, A.M.; Bayly, P.V.; Taber, L.A. Opening angles and material properties of the early embryonic chick brain. J. Biomech. Eng. 2010, 132, 011005. [CrossRef]

47. Trier, S.M.; Davidson, L.A. Quantitative microscopy and imaging tools for the mechanical analysis of morphogenesis. Curr. Opin. Genet. Dev. 2011, 21, 664-670. [CrossRef]

48. Ogden, R.W. Nonlinear Elasticity, Anisotropy, Material Stability and Residual Stresses in Soft Tissue. In Biomechanics of Soft Tissue in Cardiovascular Systems; Holzapfel, G.A., Ogden, R.W., Eds.; Springer: Vienna, Austria, 2003; pp. 65-108.

49. Buskohl, P.R.; Gould, R.A.; Butcher, J.T. Quantification of embryonic atrioventricular valve biomechanics during morphogenesis. J. Biomech. 2012, 45, 895-902. [CrossRef]

50. Zamir, E.A.; Taber, L.A. Material Properties and Residual Stress in the Stage 12 Chick Heart During Cardiac Looping. J. Biomech. Eng. 2005, 126, 823-830. [CrossRef]

51. Ogden, R.W.; Hill, R. Large deformation isotropic elasticity-On the correlation of theory and experiment for incompressible rubberlike solids. Proc. R. Soc. Lond. A Math. Phys. Sci. 1972, 326, 565-584. [CrossRef]

52. von Dassow, M.; Strother, J.A.; Davidson, L.A. Surprisingly Simple Mechanical Behavior of a Complex Embryonic Tissue. PloS ONE 2011, 5, e15359. [CrossRef] [PubMed]

53. Fung, Y.C. Biomechanics: Mechanical Properties of Living Tissues; Springer: New York, NY, USA, 1981.

54. Chuong, C.J.; Fung, Y.C. Three-Dimensional Stress Distribution in Arteries. J. Biomech. Eng. 1983, 105, 268-274. [CrossRef] [PubMed]

55. Ong, C.W.; Ren, M.; Wiputra, H.; Mojumder, J.; Chan, W.X.; Tulzer, A.; Tulzer, G.; Buist, M.L.; Mattar, C.N.; Lee, L.C.; et al. Biomechanics of Human Fetal Hearts with Critical Aortic Stenosis. Ann. Biomed. Eng. 2021, 49, 1364-1379. [CrossRef] [PubMed] 
56. Sáez, P.; Peña, E.; Martínez, M.A.; Kuhl, E. Computational modeling of hypertensive growth in the human carotid artery. Comput. Mech. 2014, 53, 1183-1196. [CrossRef] [PubMed]

57. Göktepe, S.; Acharya, S.N.S.; Wong, J.; Kuhl, E. Computational modeling of passive myocardium. Int. J. Numer. Methods Biomed. Eng. 2011, 27, 1-12. [CrossRef]

58. Lee, L.C.; Genet, M.; Acevedo-Bolton, G.; Ordovas, K.; Guccione, J.M.; Kuhl, E. A computational model that predicts reverse growth in response to mechanical unloading. Biomech. Model. Mechanobiol. 2015, 14, 217-229. [CrossRef]

59. Taber, L.A. Theoretical study of Beloussov's hyper-restoration hypothesis for mechanical regulation of morphogenesis. Biomech. Model. Mechanobiol. 2008, 7, 427-441. [CrossRef]

60. Hamburger, V.; Hamilton, H.L. A series of normal stages in the development of the chick embryo. Dev. Dyn. 1992, 195, 231-272. [CrossRef]

61. Konofagou, E.E.; D’Hooge, J.; Ophir, J. Myocardial elastography-A feasibility study in vivo. Ultrasound Med. Biol. 2002, 28, 475-482. [CrossRef]

62. Davey, M.G.; Tickle, C. The chicken as a model for embryonic development. Cytogenet. Genome Res. 2007, 117, 231-239. [CrossRef]

63. Sedmera, D.; Pexieder, T.; Rychterova, V.; Hu, N.; Clark, E.B. Remodeling of chick embryonic ventricular myoarchitecture under experimentally changed loading conditions. Anat. Rec. Off. Publ. Am. Assoc. Anat. 1999, 254, 238-252. [CrossRef]

64. Al Naieb, S.; Happel, C.M.; Yelbuz, T.M. A detailed atlas of chick heart development in vivo. Ann. Anat. 2013, 195, 324-341. [CrossRef] [PubMed]

65. Tobita, K.; Schroder, E.A.; Tinney, J.P.; Garrison, J.B.; Keller, B.B. Regional passive ventricular stress-strain relations during development of altered loads in chick embryo. Am. J. Physiol. Heart Circ. Physiol. 2002, 282, H2386-H2396. [CrossRef] [PubMed]

66. Zamir, E.A.; Taber, L.A. On the effects of residual stress in microindentation tests of soft tissue structures. J. Biomech. Eng. 2004, 126, 276-283. [CrossRef] [PubMed]

67. Miller, C.E.; Vanni, M.A.; Taber, L.A.; Keller, B.B. Passive stress-strain measurements in the stage-16 and stage-18 embryonic chick heart. J. Biomech. Eng. 1997, 119, 445-451. [CrossRef]

68. Alford, P.W.; Taber, L.A. Regional epicardial strain in the embryonic chick heart during the early looping stages. J. Biomech. 2003, 36, 1135-1141. [CrossRef]

69. Taber, L.A.; Chabert, S. Theoretical and experimental study of growth and remodeling in the developing heart. Biomech. Model. Mechanobiol. 2002, 1, 29-43. [CrossRef]

70. Zimmerman, F.J.; Hughes, S.F.; Cuneo, B.; Benson, D.W. The effect of cardiac cycle length on ventricular end-diastolic pressure and maximum time derivative of pressure in the stage 24 chick embryo. Pediatr. Res. 1991, 29, 338-346. [CrossRef]

71. Zamir, E.A.; Srinivasan, V.; Perucchio, R.; Taber, L.A. Mechanical asymmetry in the embryonic chick heart during looping. Ann. Biomed. Eng. 2003, 31, 1327-1336. [CrossRef]

72. Butcher, J.T.; McQuinn, T.C.; Sedmera, D.; Turner, D.; Markwald, R.R. Transitions in early embryonic atrioventricular valvular function correspond with changes in cushion biomechanics that are predictable by tissue composition. Circ. Res. 2007, 100, 1503-1511. [CrossRef]

73. Wang, Y.; Dur, O.; Patrick, M.J.; Tinney, J.P.; Tobita, K.; Keller, B.B.; Pekkan, K. Aortic arch morphogenesis and flow modeling in the chick embryo. Ann. Biomed. Eng. 2009, 37, 1069-1081. [CrossRef] [PubMed]

74. Celik, M.; Goktas, S.; Karakaya, C.; Cakiroglu, A.I.; Karahuseyinoglu, S.; Lashkarinia, S.S.; Ermek, E.; Pekkan, K. Microstructure of early embryonic aortic arch and its reversibility following mechanically altered hemodynamic load release. Am. J. Physiol. Heart Circ. Physiol. 2020, 318, H1208-H1218. [CrossRef] [PubMed]

75. Lindsey, S.E.; Menon, P.G.; Kowalski, W.J.; Shekhar, A.; Yalcin, H.C.; Nishimura, N.; Schaffer, C.B.; Butcher, J.T.; Pekkan, K. Growth and hemodynamics after early embryonic aortic arch occlusion. Biomech. Model. Mechanobiol. 2015, 14, 735-751. [CrossRef] [PubMed]

76. Yap, C.H.; Liu, X.; Pekkan, K. Characterization of the vessel geometry, flow mechanics and wall shear stress in the great arteries of wildtype prenatal mouse. PLoS ONE 2014, 9, e86878. [CrossRef]

77. Eghtesady, P.; Michelfelder, E.; Altaye, M.; Ballard, E.; Hirsh, R.; Beekman, R.H., 3rd. Revisiting animal models of aortic stenosis in the early gestation fetus. Ann. Thorac. Surg. 2007, 83, 631-639. [CrossRef] [PubMed]

78. O'Tierney, P.F.; Anderson, D.F.; Faber, J.J.; Louey, S.; Thornburg, K.L.; Giraud, G.D. Reduced systolic pressure load decreases cell-cycle activity in the fetal sheep heart. Am. J. Physiol. Regul. Integr. Comp. Physiol. 2010, 299, R573-R578. [CrossRef]

79. Sacks, M.S.; Yoganathan, A.P. Heart valve function: A biomechanical perspective. Philos. Trans. R. Soc. Lond. B Biol. Sci. 2007, 362, 1369-1391. [CrossRef]

80. Jett, S.; Laurence, D.; Kunkel, R.; Babu, A.R.; Kramer, K.; Baumwart, R.; Towner, R.; Wu, Y.; Lee, C.H. An investigation of the anisotropic mechanical properties and anatomical structure of porcine atrioventricular heart valves. J. Mech. Behav. Biomed. Mater. 2018, 87, 155-171. [CrossRef]

81. Khoiy, K.A.; Pant, A.D.; Amini, R. Quantification of Material Constants for a Phenomenological Constitutive Model of Porcine Tricuspid Valve Leaflets for Simulation Applications. J. Biomech. Eng. 2018, 140. [CrossRef]

82. Lodder, J.; Verkerke, G.J.; Delemarre, B.J.; Dodou, D. Morphological and mechanical properties of the posterior leaflet chordae tendineae in the mitral valve. Proc. Inst. Mech. Eng. H 2016, 230, 77-84. [CrossRef]

83. Allison, B.J.; Brain, K.L.; Niu, Y.; Kane, A.D.; Herrera, E.A.; Thakor, A.S.; Botting, K.J.; Cross, C.M.; Itani, N.; Skeffington, K.L.; et al. Fetal in vivo continuous cardiovascular function during chronic hypoxia. J. Physiol. 2016, 594, 1247-1264. [CrossRef] [PubMed] 
84. Segar, J.L.; Hajduczok, G.; Smith, B.A.; Merrill, D.C.; Robillard, J.E. Ontogeny of baroreflex control of renal sympathetic nerve activity and heart rate. Am. J. Physiol. 1992, 263, H1819-H1826. [CrossRef]

85. Huhta, H.; Junno, J.; Haapsamo, M.; Erkinaro, T.; Ohtonen, P.; Davis, L.E.; Hohimer, A.R.; Acharya, G.; Rasanen, J. Fetal sheep central haemodynamics and cardiac function during occlusion of the ascending aorta. Exp. Physiol. 2018, 103, 58-67. [CrossRef] [PubMed]

86. Tibayan, F.A.; Louey, S.; Jonker, S.; Espinoza, H.; Chattergoon, N.; You, F.; Thornburg, K.L.; Giraud, G. Increased systolic load causes adverse remodeling of fetal aortic and mitral valves. Am. J. Physiol. Regul. Integr. Comp. Physiol. 2015, 309, R1490-R1498. [CrossRef] [PubMed]

87. Rankin, J.H.; Landauer, M.; Tian, Q.; Phernetton, T.M. Cardiovascular responses to forskolin in the ovine fetus. J. Dev. Physiol. 1989, 11, 7-10. [PubMed]

88. Ishiwata, T.; Nakazawa, M.; Pu, W.T.; Tevosian, S.G.; Izumo, S. Developmental changes in ventricular diastolic function correlate with changes in ventricular myoarchitecture in normal mouse embryos. Circ. Res. 2003, 93, 857-865. [CrossRef] [PubMed]

89. Sharifi, A.; Gendernalik, A.; Garrity, D.; Bark, D. Valveless pumping behavior of the simulated embryonic heart tube as a function of contractile patterns and myocardial stiffness. Biomech. Model. Mechanobiol. 2021, 20, 2001-2012. [CrossRef]

90. Chelliah, A.; Dham, N.; Frank, L.H.; Donofrio, M.; Krishnan, A. Myocardial strain can be measured from first trimester fetal echocardiography using velocity vector imaging. Prenat. Diagn. 2016, 36, 483-488. [CrossRef]

91. van Geemen, D.; Soares, A.L.; Oomen, P.J.; Driessen-Mol, A.; Janssen-van den Broek, M.W.; van den Bogaerdt, A.J.; Bogers, A.J.; Goumans, M.J.; Baaijens, F.P.; Bouten, C.V. Age-Dependent Changes in Geometry, Tissue Composition and Mechanical Properties of Fetal to Adult Cryopreserved Human Heart Valves. PLoS ONE 2016, 11, e0149020. [CrossRef]

92. Emery, J.L.; Omens, J.H.; McCulloch, A.D. Strain softening in rat left ventricular myocardium. J. Biomech. Eng. 1997, 119, 6-12. [CrossRef]

93. Espe, E.K.; Aronsen, J.M.; Nordén, E.S.; Zhang, L.; Sjaastad, I. Regional right ventricular function in rats: A novel magnetic resonance imaging method for measurement of right ventricular strain. Am. J. Physiol. Heart Circ. Physiol. 2020, 318, H143-H153. [CrossRef] [PubMed]

94. Bolte, C.; Whitsett, J.A.; Kalin, T.V.; Kalinichenko, V.V. Transcription Factors Regulating Embryonic Development of Pulmonary Vasculature. Adv. Anat. Embryol. Cell Biol. 2018, 228, 1-20. [PubMed]

95. Deng, Y.; Ou, Z.; Li, R.; Chen, Z.; Liang, P.; Sun, L. Affected-embryo-based SNP haplotyping with NGS for the preimplantation genetic testing of Marfan syndrome. Syst. Biol. Reprod. Med. 2021, 67, 298-306. [CrossRef] [PubMed]

96. Cardoso, S.; Robertson, S.P.; Daniel, P.B. TGFBR1 mutations associated with Loeys-Dietz syndrome are inactivating. J. Recept. Signal. Transduct. Res. 2012, 32, 150-155. [CrossRef] [PubMed]

97. Park, A.C.; Phillips, C.L.; Pfeiffer, F.M.; Roenneburg, D.A.; Kernien, J.F.; Adams, S.M.; Davidson, J.M.; Birk, D.E.; Greenspan, D.S. Homozygosity and Heterozygosity for Null Col5a2 Alleles Produce Embryonic Lethality and a Novel Classic Ehlers-Danlos Syndrome-Related Phenotype. Am. J. Pathol. 2015, 185, 2000-2011. [CrossRef]

98. Palit, A.; Bhudia, S.K.; Arvanitis, T.N.; Turley, G.A.; Williams, M.A. Computational modelling of left-ventricular diastolic mechanics: Effect of fibre orientation and right-ventricle topology. J. Biomech. 2015, 48, 604-612. [CrossRef]

99. Kathiriya, I.S.; Srivastava, D. Left-right asymmetry and cardiac looping: Implications for cardiac development and congenital heart disease. Am. J. Med. Genet. 2000, 97, 271-279. [CrossRef]

100. Huang, Y.; Zheng, L.; Gong, X.; Jia, X.; Song, W.; Liu, M.; Fan, Y. Effect of cyclic strain on cardiomyogenic differentiation of rat bone marrow derived mesenchymal stem cells. PLOS ONE 2012, 7, e34960.

101. Cattaruzza, M.; Guzik, T.J.; Slodowski, W.; Pelvan, A.; Becker, J.; Halle, M.; Buchwald, A.B.; Channon, K.M.; Hecker, M. Shear stress insensitivity of endothelial nitric oxide synthase expression as a genetic risk factor for coronary heart disease. Circ. Res. 2004, 95, 841-847. [CrossRef]

102. Groenendijk, B.C.; Van der Heiden, K.; Hierck, B.P.; Poelmann, R.E. The role of shear stress on ET-1, KLF2, and NOS-3 expression in the developing cardiovascular system of chicken embryos in a venous ligation model. Physiology 2007, 22, 380-389. [CrossRef]

103. Egorova, A.D.; Van der Heiden, K.; Van de Pas, S.; Vennemann, P.; Poelma, C.; DeRuiter, M.C.; Goumans, M.J.; Gittenberger-de Groot, A.C.; ten Dijke, P.; Poelmann, R.E.; et al. Tgfbeta/Alk5 signaling is required for shear stress induced klf2 expression in embryonic endothelial cells. Dev. Dyn. 2011, 240, 1670-1680. [CrossRef] [PubMed]

104. Kumar, S.D.; Yong, S.K.; Dheen, S.T.; Bay, B.H.; Tay, S.S. Cardiac malformations are associated with altered expression of vascular endothelial growth factor and endothelial nitric oxide synthase genes in embryos of diabetic mice. Exp. Biol. Med. 2008, 233, 1421-1432. [CrossRef] [PubMed]

105. Lacolley, P.; Challande, P.; Osborne-Pellegrin, M.; Regnault, V. Genetics and pathophysiology of arterial stiffness. Cardiovasc. Res. 2009, 81, 637-648. [CrossRef] [PubMed]

106. Li, Y.; Zheng, J.; Bird, I.M.; Magness, R.R. Effects of pulsatile shear stress on nitric oxide production and endothelial cell nitric oxide synthase expression by ovine fetoplacental artery endothelial cells. Biol. Reprod. 2003, 69, 1053-1059.

107. Novodvorsky, P.; Chico, T.J. The role of the transcription factor KLF2 in vascular development and disease. Prog. Mol. Biol. Transl. Sci. 2014, 124, 155-188.

108. Malek, A.M.; Zhang, J.; Jiang, J.; Alper, S.L.; Izumo, S. Endothelin-1 gene suppression by shear stress: Pharmacological evaluation of the role of tyrosine kinase, intracellular calcium, cytoskeleton, and mechanosensitive channels. J. Mol. Cell Cardiol. 1999, 31, 387-399. [CrossRef] 
109. Halabi, C.M.; Broekelmann, T.J.; Lin, M.; Lee, V.S.; Chu, M.L.; Mecham, R.P. Fibulin-4 is essential for maintaining arterial wall integrity in conduit but not muscular arteries. Sci. Adv. 2017, 3, e1602532.

110. Staiculescu, M.C.; Cocciolone, A.J.; Procknow, J.D.; Kim, J.; Wagenseil, J.E. Comparative gene array analyses of severe elastic fiber defects in late embryonic and newborn mouse aorta. Physiol. Genom. 2018, 50, 988-1001. [CrossRef]

111. Igoucheva, O.; Alexeev, V.; Halabi, C.M.; Adams, S.M.; Stoilov, I.; Sasaki, T.; Arita, M.; Donahue, A.; Mecham, R.P.; Birk, D.E.; et al. Fibulin-4 E57K Knock-in Mice Recapitulate Cutaneous, Vascular and Skeletal Defects of Recessive Cutis Laxa 1B with both Elastic Fiber and Collagen Fibril Abnormalities. J. Biol. Chem. 2015, 290, 21443-21459. [CrossRef]

112. Kim, J.; Procknow, J.D.; Yanagisawa, H.; Wagenseil, J.E. Differences in genetic signaling, and not mechanical properties of the wall, are linked to ascending aortic aneurysms in fibulin-4 knockout mice. Am. J. Physiol. Heart Circ. Physiol. 2015, 309, H103-H113.

113. Stephens, E.H.; Post, A.D.; Laucirica, D.R.; Grande-Allen, K.J. Perinatal changes in mitral and aortic valve structure and composition. Pediatr. Dev. Pathol. 2010, 13, 447-458. [CrossRef] [PubMed]

114. Toda, M.; Yamamoto, K.; Shimizu, N.; Obi, S.; Kumagaya, S.; Igarashi, T.; Kamiya, A.; Ando, J. Differential gene responses in endothelial cells exposed to a combination of shear stress and cyclic stretch. J. Biotechnol. 2008, 133, 239-244. [CrossRef] [PubMed]

115. Montgomery, M.O.; Jiao, Y.; Phillips, S.J.; Singh, G.; Xu, J.; Balsara, R.; Litvin, J. Alterations in sheep fetal right ventricular tissue with induced hemodynamic pressure overload. Basic Res. Cardiol. 1998, 93, 192-200. [CrossRef] [PubMed]

116. Zhao, Z. Cardiac malformations and alteration of TGFbeta signaling system in diabetic embryopathy. Birth Defects Res. $B$ Dev. Reprod. Toxicol. 2010, 89, 97-105.

117. Renard, M.; Holm, T.; Veith, R.; Callewaert, B.L.; Adès, L.C.; Baspinar, O.; Pickart, A.; Dasouki, M.; Hoyer, J.; Rauch, A.; et al. Altered TGFbeta signaling and cardiovascular manifestations in patients with autosomal recessive cutis laxa type I caused by fibulin-4 deficiency. Eur. J. Hum. Genet. 2010, 18, 895-901. [CrossRef]

118. Ai, J.; Zhang, R.; Gao, X.; Niu, H.F.; Wang, N.; Xu, Y.; Li, Y.; Ma, N.; Sun, L.H.; Pan, Z.W.; et al. Overexpression of microRNA-1 impairs cardiac contractile function by damaging sarcomere assembly. Cardiovasc. Res. 2012, 95, 385-393. [CrossRef]

119. Witman, N.; Heigwer, J.; Thaler, B.; Lui, W.O.; Morrison, J.I. miR-128 regulates non-myocyte hyperplasia, deposition of extracellular matrix and Islet1 expression during newt cardiac regeneration. Dev. Biol. 2013, 383, 253-263. [CrossRef]

120. Bowen, C.J.; Zhou, J.; Sung, D.C.; Butcher, J.T. Cadherin-11 coordinates cellular migration and extracellular matrix remodeling during aortic valve maturation. Dev. Biol. 2015, 407, 145-157. [CrossRef]

121. Sung, D.C.; Bowen, C.J.; Vaidya, K.A.; Zhou, J.; Chapurin, N.; Recknagel, A.; Zhou, B.; Chen, J.; Kotlikoff, M.; Butcher, J.T. Cadherin-11 Overexpression Induces Extracellular Matrix Remodeling and Calcification in Mature Aortic Valves. Arterioscler. Thromb. Vasc. Biol. 2016, 36, 1627-1637. [CrossRef]

122. Lehoux, S.; Tedgui, A. Cellular mechanics and gene expression in blood vessels. J. Biomech. 2003, 36, 631-643. [CrossRef]

123. Lehoux, S.; Castier, Y.; Tedgui, A. Molecular mechanisms of the vascular responses to haemodynamic forces. J. Intern. Med. 2006, 259, 381-392. [CrossRef] [PubMed]

124. Luyckx, I.; MacCarrick, G.; Kempers, M.; Meester, J.; Geryl, C.; Rombouts, O.; Peeters, N.; Claes, C.; Boeckx, N.; Sakalihasan, N.; et al. Confirmation of the role of pathogenic SMAD6 variants in bicuspid aortic valve-related aortopathy. Eur. J. Hum. Genet. 2019, 27, 1044-1053. [CrossRef]

125. Tseng, C.C.S.; Huibers, M.M.H.; van Kuik, J.; de Weger, R.A.; Vink, A.; de Jonge, N. The Interleukin-33/ST2 Pathway Is Expressed in the Failing Human Heart and Associated with Pro-fibrotic Remodeling of the Myocardium. J. Cardiovasc. Transl. Res. 2018, 11, 15-21. [CrossRef]

126. Veeraveedu, P.T.; Sanada, S.; Okuda, K.; Fu, H.Y.; Matsuzaki, T.; Araki, R.; Yamato, M.; Yasuda, K.; Sakata, Y.; Yoshimoto, T.; et al. Ablation of IL-33 gene exacerbate myocardial remodeling in mice with heart failure induced by mechanical stress. Biochem. Pharmacol. 2017, 138, 73-80. [CrossRef] [PubMed]

127. O'Shaughnessy, K.M. Genetics of arterial structure and function: Towards new biomarkers for aortic stiffness? Clin. Sci. 2008, 114, 661-677.

128. Carta, L.; Wagenseil, J.E.; Knutsen, R.H.; Mariko, B.; Faury, G.; Davis, E.C.; Starcher, B.; Mecham, R.P.; Ramirez, F. Discrete contributions of elastic fiber components to arterial development and mechanical compliance. Arterioscler. Thromb. Vasc. Biol. 2009, 29, 2083-2089. [CrossRef]

129. Wagenseil, J.E.; Mecham, R.P. Elastin in large artery stiffness and hypertension. J. Cardiovasc. Transl. Res. 2012, 5, 264-273. [CrossRef]

130. Bordeleau, F.; Mason, B.N.; Lollis, E.M.; Mazzola, M.; Zanotelli, M.R.; Somasegar, S.; Califano, J.P.; Montague, C.; LaValley, D.J.; Huynh, J.; et al. Matrix stiffening promotes a tumor vasculature phenotype. Proc. Natl. Acad. Sci. USA 2017, 114, $492-497$. [CrossRef]

131. Makwana, O.; King, N.M.; Ahles, L.; Selmin, O.; Granzier, H.L.; Runyan, R.B. Exposure to low-dose trichloroethylene alters shear stress gene expression and function in the developing chick heart. Cardiovasc. Toxicol. 2010, 10, 100-107. [CrossRef]

132. Gould, R.A.; Aziz, H.; Woods, C.E.; Seman-Senderos, M.A.; Sparks, E.; Preuss, C.; Wünnemann, F.; Bedja, D.; Moats, C.R.; McClymont, S.A.; et al. ROBO4 variants predispose individuals to bicuspid aortic valve and thoracic aortic aneurysm. Nat. Genet. 2019, 51, 42-50. [CrossRef] 
133. Koenig, S.N.; LaHaye, S.; Feller, J.D.; Rowland, P.; Hor, K.N.; Trask, A.J.; Janssen, P.M.; Radtke, F.; Lilly, B.; Garg, V. Notch1 haploinsufficiency causes ascending aortic aneurysms in mice. JCI Insight 2017, 2, e91353. [CrossRef] [PubMed]

134. Laurent, S.; Boutouyrie, P.; Lacolley, P. Structural and genetic bases of arterial stiffness. Hypertension 2005, 45, 1050-1055. [CrossRef] [PubMed]

135. Puzzi, L.; Borin, D.; Gurha, P.; Lombardi, R.; Martinelli, V.; Weiss, M.; Andolfi, L.; Lazzarino, M.; Mestroni, L.; Marian, A.J.; et al. Knock Down of Plakophillin 2 Dysregulates Adhesion Pathway through Upregulation of miR200b and Alters the Mechanical Properties in Cardiac Cells. Cells 2019, 8, 1639. [CrossRef] [PubMed] 